Technical Report

September 1994

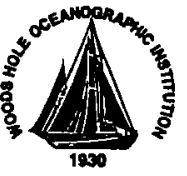

\title{
Calibration History of Some Rotronic MP-100 and Vaisala Humicap Relative Humidity Sensors
}

by

Richard E. Payne

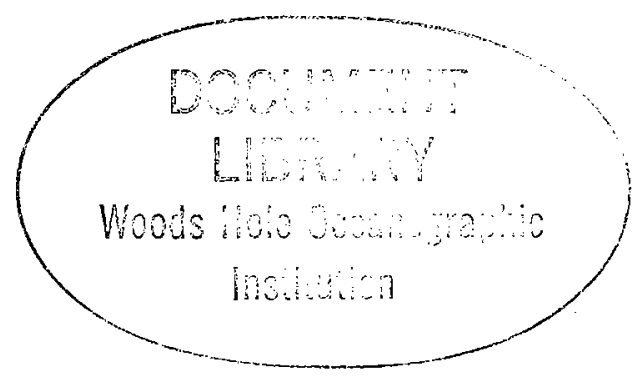

Upper Ocean Processes Group

Woods Hole Oceanographic Institution

Woods Hole, Massachusetts 02543 U.S.A.

UOP Technical Report 94-3 


\section{WHOI-94-28}

UOP Report 943

\section{Calibration History of Some Rotronic MP-100 and Vaisala Humicap \\ Relative Humidity Sensors}

by

Richard E. Payne

Woods Hole Oceanographic Institution Woods Hole, Massachusetts 02543 U.S.A.

September 1994

\section{Technical Report}

Funding was provided by the National Science Foundation, under Grant No. OCE-91-15000.

Reproduction in whole or in part is permitted for any purpose of the United States Government. This report should be cited as Woods Hole Oceanog. Inst. Tech. Rept., WHOI-94-28.

Approved for public release; distribution unlimited.

\section{Approved for Distribution:}

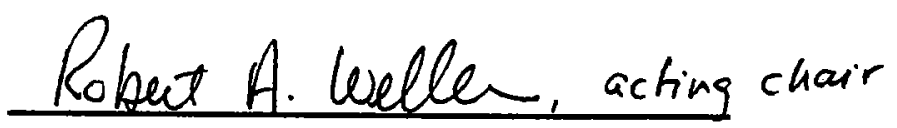

Philip L. Richardson, Chair

Department of Physical Oceanography 


\section{Abstract}

An analysis has been made of the calibrations done during 1990 through 1994 on Rotronic MP-100 relative humidity sensors (used in the Improved METeorological (IMET) system) and sensors built at the Woods Hole Oceanographic Institution (WHOI) with the Vaisala Humicap sensing element (used in the Vector Averaging Wind Recorder (VAWR)). The shift from one calibration to the next is, typically, $2-3 \% \mathrm{RH}$ which represents the major uncertainty in relative humidity with either of these sensors. The direction of each shift appears to be random; thus, there does not appear to be any long-term drifts. 


\section{Table of Contents}

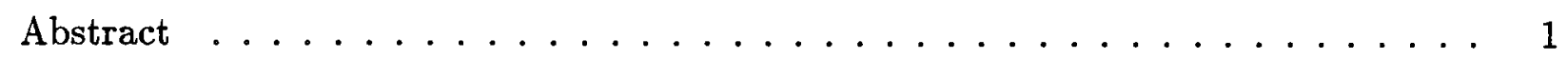

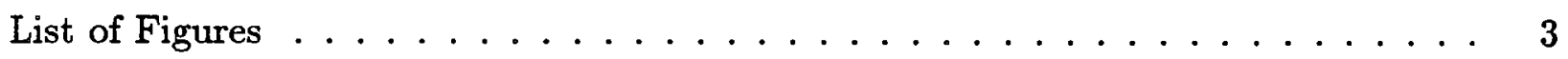

List of Tables . . . . . . . . . . . . . . . . 4

1. Introduction $\ldots \ldots \ldots \ldots \ldots \ldots \ldots \ldots \ldots \ldots \ldots \ldots \ldots \ldots \ldots \ldots \ldots \ldots \ldots$

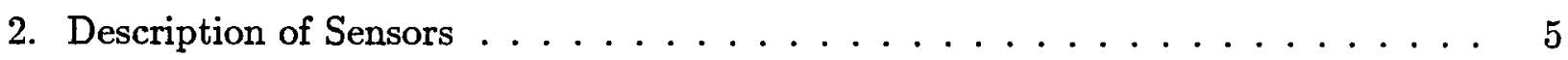

3. Data.......................... 6

4. IMET Calibration Data $\ldots \ldots \ldots \ldots \ldots \ldots \ldots \ldots$

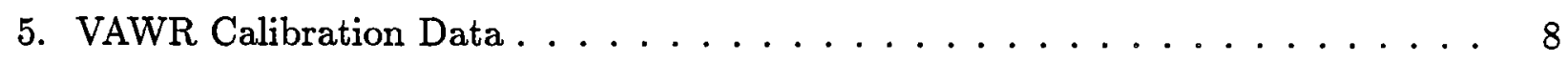

6. Temperature Dependence of Relative Humidity Sensors . . . . . . . . . . 8

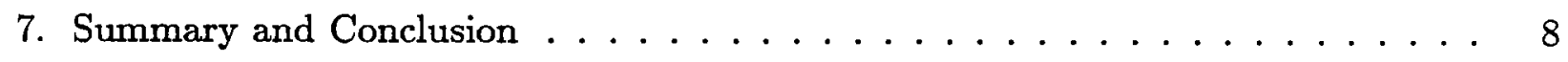

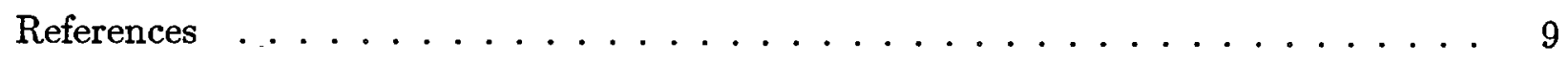

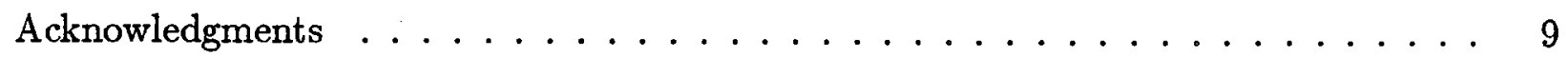




\section{List of Figures}

1. Error in computed relative humidity $\ldots \ldots \ldots \ldots \ldots \ldots$

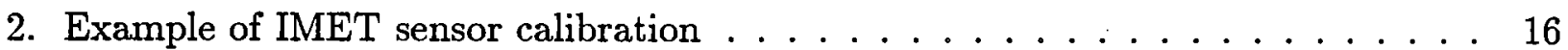

3. Shifts in IMET sensor calibrations at $20 \% \mathrm{RH} \ldots \ldots \ldots \ldots \ldots$

4. Shifts in IMET sensor calibrations at $30 \% \mathrm{RH} \ldots \ldots \ldots \ldots \ldots$

5. Shifts in IMET sensor calibrations at $40 \% \mathrm{RH} \ldots \ldots \ldots \ldots$

6. Shifts in IMET sensor calibrations at $50 \% \mathrm{RH} \ldots \ldots \ldots \ldots$

7. Shifts in IMET sensor calibrations at $60 \%$ RH $\ldots \ldots \ldots \ldots \ldots \ldots$

8. Shifts in IMET sensor calibrations at $70 \% \mathrm{RH} \ldots \ldots \ldots \ldots . \ldots \ldots 22$

9. Shifts in IMET sensor calibrations at $80 \% \mathrm{RH} \ldots \ldots \ldots \ldots \ldots$

10. Shifts in IMET sensor calibrations at $90 \% \mathrm{RH} \ldots \ldots \ldots \ldots$

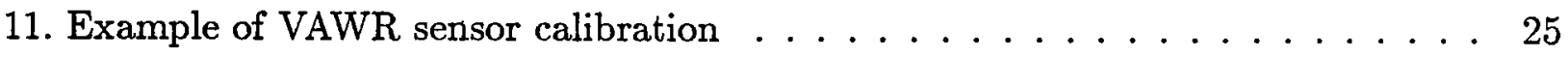

12. Shifts in VAWR sensor calibrations at $20 \% \mathrm{RH} \ldots \ldots \ldots \ldots$

13. Shifts in VAWR sensor calibrations at $30 \% \mathrm{RH} \ldots \ldots \ldots \ldots . \ldots \ldots$

14. Shifts in VAWR sensor calibrations at $40 \% \mathrm{RH} \ldots \ldots \ldots \ldots$

15. Shifts in VAWR sensor calibrations at $50 \% \mathrm{RH} \ldots \ldots \ldots \ldots . \ldots \ldots$

16. Shifts in VAWR sensor calibrations at $60 \% \mathrm{RH} \ldots \ldots \ldots \ldots$

17. Shifts in VAWR sensor calibrations at $70 \% \mathrm{RH} \ldots \ldots \ldots 31$

18. Shifts in VAWR sensor calibrations at $80 \%$ RH $\ldots \ldots \ldots \ldots 32$

19. Shifts in VAWR sensor calibrations at $90 \% \mathrm{RH} \ldots \ldots \ldots \ldots \ldots$ 


\section{List of Tables}

1. Example of report of IMET sensor calibration . . . . . . . . . . . . . . 10

2. Summary of IMET shifts between calibrations . . . . . . . . . . . . . 11

3. Example of report of VAWR sensor calibration . . . . . . . . . . . . . 12

4. Summary of VAWR shifts between calibrations . . . . . . . . . . . . 13

5. Summary of IMET shifts due to $10^{\circ} \mathrm{C}$ temperature difference . . . . . . . . . 14

6. Summary of VAWR shifts due to $10^{\circ} \mathrm{C}$ temperature difference . . . . . . . . . 14 


\section{Introduction}

The IMET package was developed by the Upper Ocean Processes Group (UOP) at WHOI for measuring the surface meteorological parameters required for the computation of heat and momentum fluxes at sea surface from buoys (Hosom et al., 1994). These measured variables include wind velocity, air temperature, sea temperature, relative humidity, barometric pressure, shortwave and longwave radiation and precipitation. Of all these variables, relative humidity is a significant parameter since it is required for the calculation of latent heat flux, which is generally the largest heat flux from the sea to the atmosphere. After testing several prospective sensors, the Rotronic MP-100F was selected for use in the IMET relative humidity module (Crescenti et al., 1990), because of its accuracy and reliability.

The VAWR measures a similar set of parameters, except precipitation, and has been used by the UOP group for a number of years. Its conversion from the Vector Averaging Current Meter (VACM) was first accomplished for the JASIN-72 experiment (Payne, 1974), and its present form is described in Dean and Beardsley (1988) and Trask et al. (1989). Its success has been due to its very high reliability and very low power consumption. The relative humidity sensor used with it has a Vaisala Humicap sensor element with electronics developed at WHOI (Trask et al., 1989). As with the IMET relative humidity sensor, this sensor has proved accurate and reliable, consistent with the required specifications needed for measuring meteorological parameters.

\section{Description of Sensors}

The Rotronic MP-100F sensor has a thin film polymer capacitative relative humidity element and a platinum film temperature element. The sensor electronics provide a nominal 0-1 volt output for each, corresponding to 0 to $100 \% \mathrm{RH}$ and -30 to $+70^{\circ} \mathrm{C}$, respectively. The manufacturer's accuracy specifications are $\pm 2.0 \% \mathrm{RH}$ from 0 to $100 \% \mathrm{RH}$ and $\pm 0.5^{\circ} \mathrm{C}$. Each relative humidity IMET module has had a Rotronic sensor dedicated to it. No exchanges of sensors have been made in any of the modules analyzed nor have any adjustments been made to the Rotronic sensors or module A/Ds unless there was some kind of failure. In the case of such a failure, the calibration data prior to the failure have been deleted from the results.

The voltages from the Rotronic sensor are digitized in the IMET module by a 15 bit A/D. Testing of these shows that they are extremely stable and precise so the error contributed to the relative humidity measurement by the $A / D$ or associated electronics is an insignificant part of the total error. 
For the VAWR sensor, the sensor electronics convert the capacitance of the thin film polymer capacitative Humicap element into a frequency which is an analog of relative humidity. The frequency output is much more convenient to handle in the VAWR than an analog voltage. Until now, the sensor has had no provision for measuring air temperature.

\section{Data}

Each IMET relative humidity sensor and module has been calibrated as a unit before and after each deployment. Over the three years since deployments began we have accumulated a sufficiently substantial body of successive calibrations on the modules to make a meaningful examination of the results. The VAWR sensors are also calibrated before and after each deployment. In their case, however, the sensor is calibrated alone with the period of the output recorded. High-quality calibrations of the VAWR sensors also began in early 1991. Since they have been used more frequently, we have more calibration data for them.

Both IMET modules and VAWR sensors are calibrated in a Tecnequip relative humidity chamber using, as a standard, a General Eastern Model 1500 Hygrocomputer with a Model $1211 \mathrm{HX}$ optical sensor and air temperature sensor attached (and in the chamber). The chamber is microprocessor controlled and settings are repeatable to a few percent $\mathrm{RH}$ and $1^{\circ} \mathrm{C}$. The chamber holds constant to $0.1 \% \mathrm{RH}$ and $0.1^{\circ} \mathrm{C}$ for long periods of time. The General Eastern combination measures air and dew point temperatures to $0.1^{\circ} \mathrm{C}$ accuracy and computes relative humidity as well as temperature. The General Eastern Model 1500 and sensors are calibrated annually and have shown no signs of drift beyond the $0.1^{\circ} \mathrm{C}$.

The error in measuring temperature leads to an error in the calculated $\mathrm{RH}$ which varies with relataive humidity. Figure 1 shows the error in $\% \mathrm{RH}$ to be expected from a $0.1^{\circ} \mathrm{C}$ error in dew point temperature for three ambient temperatures. It is apparent that it varies from about 0.2 to about $0.6 \% \mathrm{RH}$ over the range of relative humidities we may expect to see but varies slowly with air temperature at a given $R H$ value. Since relative humidity is computed from both air and dew point temperatures and both have the same uncertainty, the possible error in the chamber relative humidities is double the graph values, or 0.4 to $1.2 \% \mathrm{RH}$. This represents the calibration accuracy of the sensors.

Since we have not used the air temperature measured at the Rotronic sensor in the past, only a rough calibration check has been made on this parameter. We are continually refining our methods, however, and will, in the immediate future, begin using these temperatures to correct the relative humidity values to the ambient temperature as measured by the IMET or VAWR air temperature sensor. Because of this, we are modifying the VAWR 
sensors to measure temperature and have begun making precise calibrations, in a water bath, of the relative humidity air temperature measurements. Since these calibrations have only recently begun, we have nothing to report on yet.

\section{IMET Calibration Data}

Table 1 is the report from a recent calibration of one of the IMET modules. Figure 2 is a plot of the data and the curve fitted to it. Note that the fit is done for the counts out of the A/D. At the bottom of Table 1 is a table of standard outputs for all the calibrations which have been done on the sensor. The first column is a standard set of count values used for every module. The rest of the table is the result of substituting these count values into the equation under the heading "FIT STATISTICS" for each of the calibrations. Although the absolute value of each individual table entry has little meaning, the variation from one to another across the table gives a quantitative measure of how much the calibration curve of the sensor has shifted between calibrations as a function of relative humidity.

Table 2 is a distillation of the standard output table from all the IMET modules. Listed are the module number, the number of days since the previous calibration, and the differences between the standard output table value for a given count value and date and the previous calibration set of these numbers for relative humidities of $20-90 \% \mathrm{RH}$. Thus, this is a history of the calibration shifts of all the modules. At the bottom of the table are the mean value for each nominal $\mathrm{RH}$ value and the standard deviation about that mean for all the sensors in the table. Figures 3 to 10 are plots of the table values for nominal relative humidities of $20-90 \% \mathrm{RH}$ at $10 \% \mathrm{RH}$ intervals. From these figures and Table 2 it is apparent that most of the differences are within $\pm 3 \% \mathrm{RH}$ of zero and are nearly independent of the actual relative humidity value. We would expect to see a positive correlation between the RH differences and time if the sensors tended to drift steadily with time, i.e., a longer time between successive calibrations would yield a larger shift. Since none is apparent, we conclude that the differences between calibrations are random and represent the true uncertainty in relative humidity measurements with these sensors. From the standard deviations, the uncertainty ranges from $\pm 2 \% \mathrm{RH}$ at low relative humidities to $\pm 3 \% \mathrm{RH}$ at high values. Since this uncertainty is a factor of 6 larger than the uncertainty in our calibrations, we conclude that this is the limit of accuracy of the Rotronic sensors and the source of the dominant error in each measurement. 


\section{VAWR Calibration Data}

Table 3 is the report from a VAWR sensor calibration study. In this case the fit is done to the period of the output of the sensor. Figure 11 is a plot of the data and the curve fitted to it. The quantities in both Table 3 and Figure 11 are analogous to those for the IMET sensors in Table 1 and Figure 2.

Table 4 is a compilation of all the calibration data from the VAWR sensors similar to that for the IMET modules in Table 2. Figures 12 to 19 are plots of the table values for nominal relative humidities of $20-90 \% \mathrm{RH}$ at $10 \% \mathrm{RH}$ intervals. For the VAWR sensors there is a much larger variation of calibration shift with relative humidity although the maximum values are similar in magnitude. The values are quite small at low relative humidities and of a size similar to those of the IMET at high humidities. Since relative humidity values at sea are rarely below $50 \% \mathrm{RH}$, the uncertainty in values measured by the VAWR in typical conditions is \pm 2 to $3 \% \mathrm{RH}$, equivalent to that of the IMET.

\section{Temperature Dependence of Relative Humidity Sensors}

Table 5 shows the differences between calibrations at $10^{\circ} \mathrm{C}$ and $20^{\circ} \mathrm{C}$ on successive days at a variety of nominal relative humidity values for six IMET modules. It is apparent that a temperature shift of $10^{\circ} \mathrm{C}$ causes a shift of the order of $-2 \% \mathrm{RH}$ in the output of the sensor at low relative humidities and $+1-2 \% \mathrm{RH}$ at high humidities. Again, because of the $A / D$ design, this temperature dependence is very likely in the Rotronic sensor.

Table 6 shows the equivalent temperature effect in the VAWR relative humidity sensor. In the relative humidity region that most interests us the magnitude of the effect is of order $1 \% \mathrm{RH}$ or less for the $10^{\circ} \mathrm{C}$ difference.

Both the IMET and VAWR show a temperature dependence which should be accounted for in the use of data from them.

\section{Summary and Conclusion}

Analysis of calibration results for both IMET modules and the VAWR sensors designed and built at WHOI shows that both have random shifts in their calibrations of \pm 2 to $3 \% \mathrm{RH}$ in the range of humidities usually experienced at sea. This represents the major uncertainty in measurements made with the sensors. A smaller, and undetermined, error results from the uncorrected temperature dependence of both type of sensors. 


\section{References}

Crescenti, Gennaro H., Richard E. Payne, and Robert A. Weller, 1990. Improved Meteorological Measurements from Buoys and Ships (IMET): Preliminary Comparison of Humidity Sensors. Woods Hole Oceanographic Institution, Technical Report WHOI90-18, 57 pp.

Dean, Jerome P., and Robert C. Beardsley, 1988. A vector averaging wind recorder (VAWR) system for surface meteorological measurements in CODE. Woods Hole Oceanographic Institution, Technical Report, WHOI-88-20, 68 pp.

Payne, Richard E., 1974. A buoy mounted meteorological recording package. Woods Hole Oceanographic Institution, Technical Report WHOI-74-40, 31 pp.

Trask, Richard P., Jerome P. Dean, James R. Valdes, and Craig D. Marquette, 1989. FASINEX (Frontal Air-Sea Interaction Experiment) Moored Instrumentation. Woods Hole Oceanographic Institution, Technical Report WHOI-89-3, 60 pp.

Hosom, David S., Robert A. Weller, Richard E. Payne, and Kenneth E. Prada, 1994. The IMET (Improved METeorology) Ship and Buoy Systems. Journal of Atmospheric and Oceanic Technology, accepted.

\section{Acknowledgments}

The production of this report was supported by the National Science Foundation, grant number OCE-91-15000. 


\section{Table 1: Example of report of IMET sensor calibration}

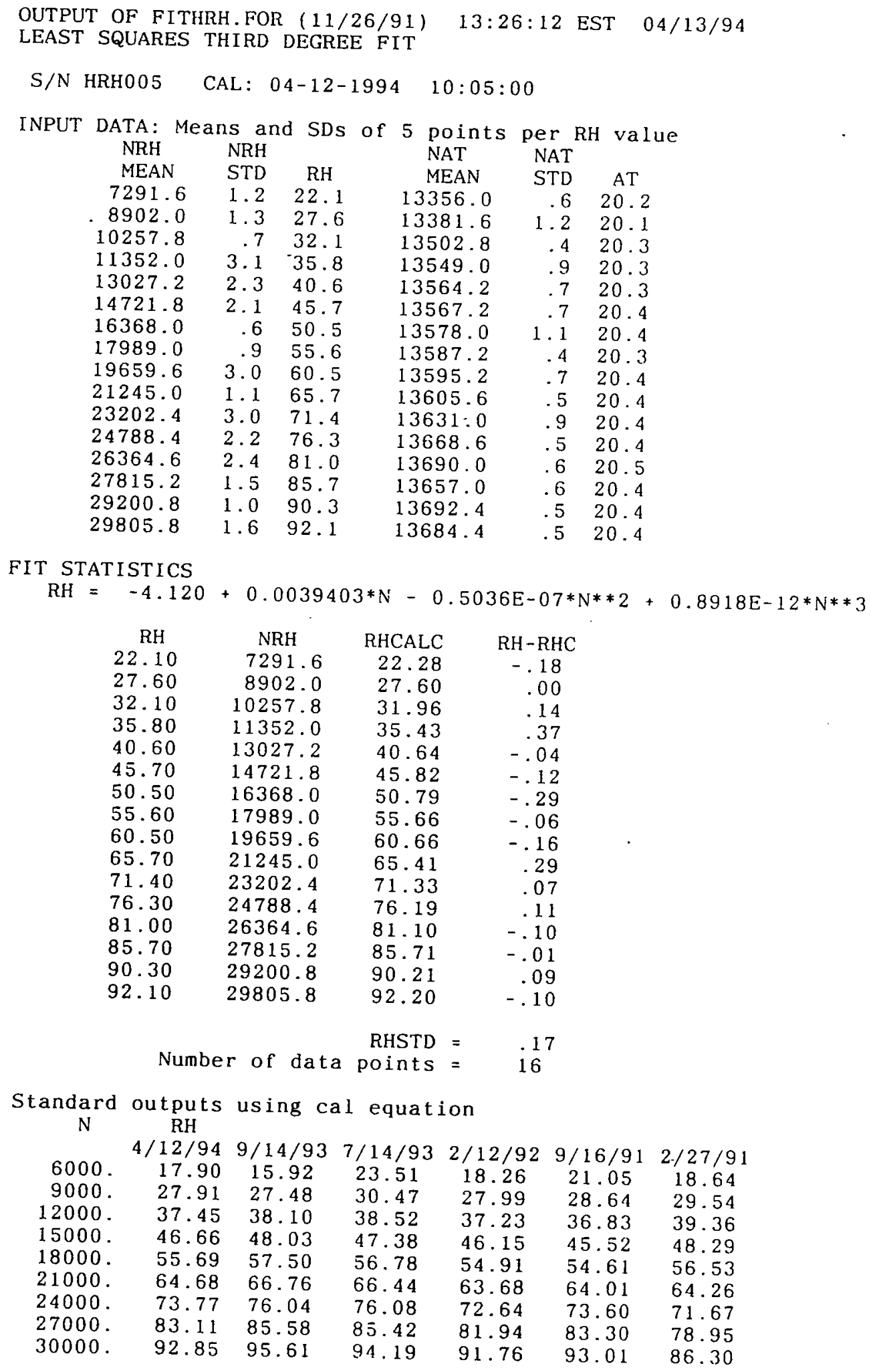


Table 2: Summary of IMET shifts between calibrations

\begin{tabular}{|c|c|c|c|c|c|c|c|c|c|}
\hline MOD & DYD & 20 & 30 & 40 & 50 & 60 & 70 & 80 & $90 \%$ \\
\hline HRHOO1 & 436.0 & 2.96 & 3.08 & 2.93 & 2.58 & 2.10 & 1.59 & -6.88 & .79 \\
\hline HRHOO1 & 480.0 & -.93 & -.83 & -.71 & -.58 & -.43 & -.28 & -.13 & .02 \\
\hline HRHOO2 & 436.0 & -1.83 & -1.89 & -2.01 & -2.12 & -2.13 & -1.96 & -1.53 & -.76 \\
\hline HRHOO2 & 480.0 & -3.78 & -4.55 & -4.86 & -4.82 & -4.55 & -4.17 & -3.79 & -3.52 \\
\hline HRHOO3 & 514.0 & -.60 & -.87 & -.62 & -.02 & .76 & 1.56 & 2.23 & 2.58 \\
\hline HRHOO4 & 74.0 & -1.76 & -1.35 & -.72 & .02 & .80 & 1.52 & 2.08 & 2.40 \\
\hline HRHOO4 & 129.0 & 1.48 & .10 & -.38 & -.22 & .30 & .92 & 1.35 & 1.33 \\
\hline HRHOO4 & 70.0 & -.62 & .40 & .98 & 1.22 & 1.17 & .92 & .55 & .12 \\
\hline HRHOO4 & 198.0 & -1.58 & -1.38 & -1.52 & -1.82 & -2.10 & -2.20 & -1.94 & -1.12 \\
\hline HRHOO4 & 78.0 & 2.89 & 2.84 & 2.80 & 2.73 & 2.62 & 2.42 & 2.12 & 1.67 \\
\hline HRHOO4 & 180.0 & -.72 & -.13 & .11 & .07 & -.12 & -.37 & -.55 & -.56 \\
\hline HRHOO4 & 329.0 & 1.90 & 1.81 & 1.81 & 1.97 & 2.27 & 2.79 & 3.52 & 4.51 \\
\hline HRHOO5 & 201.0 & -.90 & -2.53 & -2.77 & -1.92 & -.25 & 1.93 & 4.35 & 6.71 \\
\hline HRHOOS & 149.0 & -.65 & .40 & .63 & .30 & -.33 & -.96 & -1.36 & -1.25 \\
\hline HRHOO5 & 518.0 & 2.48 & 1.29 & 1.23 & 1.87 & 2.76 & 3.44 & 3.48 & 2.43 \\
\hline HRHOO5 & 62.0 & -2.99 & -.42 & .65 & .72 & .32 & -.04 & .16 & 1.42 \\
\hline HRHOO5 & 210.0 & .43 & -.65 & -1.37 & -1.81 & -2.08 & -2.27 & -2.47 & -2.76 \\
\hline HRHOO6 & 271.0 & -1.35 & -1.94 & -2.19 & -2.15 & -1.90 & -1.50 & -1.03 & -.54 \\
\hline HRHOO6 & 456.0 & -.67 & .27 & .77 & .95 & .91 & .75 & .60 & .54 \\
\hline HRHOO 6 & 329.0 & 2.58 & 2.46 & 2.43 & 2.48 & 2.58 & 2.73 & 2.88 & 3.04 \\
\hline HRH 101 & 78.0 & 2.89 & 2.84 & 2.80 & 2.73 & 2.62 & 2.42 & 2.12 & 1.67 \\
\hline HRH 101 & 181.0 & -1.45 & -1.48 & -1.83 & -2.29 & -2.70 & -2.85 & -2.56 & -1.63 \\
\hline HRH 101 & 328.0 & -.01 & -.65 & -.79 & -.60 & -.20 & .26 & .63 & $: 76$ \\
\hline HRH 102 & 39.0 & .22 & .71 & .91 & .93 & .87 & .81 & .84 & 1.08 \\
\hline HRH 102 & 202.0 & -2.25 & -1.85 & -1.66 & -1.60 & -1.59 & -1.54 & -1.38 & -1.02 \\
\hline HRH102 & 238.0 & -1.00 & -.97 & -1.23 & -1.69 & -2.23 & -2.78 & -3.23 & -3.49 \\
\hline HRH 102 & 292.0 & 1.72 & 1.80 & 2.05 & 2.40 & 2.78 & 3.13 & 3.41 & 3.53 \\
\hline HRH 103 & 481.0 & -1.72 & -2.21 & -2.59 & -2.82 & -2.89 & -2.81 & -2.55 & -2.11 \\
\hline HRH 104 & 458.0 & -.66 & -.37 & -.68 & -1.32 & -1.99 & -2.42 & -2.35 & -1.51 \\
\hline HRH 106 & 458.0 & -.49 & -.29 & -.56 & -1.11 & -1.74 & -2.26 & -2.46 & -5.16 \\
\hline HRH 107 & 591.0 & -1.57 & -1.17 & -.85 & -.61 & -.42 & -.25 & -.09 & .08 \\
\hline HRH 107 & 225.0 & 1.27 & 1.62 & 1.63 & 1.34 & .96 & .56 & .50 & 1.48 \\
\hline HRH 108 & 202.0 & -.92 & -.47 & -.20 & -.07 & -.03 & -.03 & -.02 & .04 \\
\hline HRH 108 & 587.0 & -1.67 & -2.92 & -3.90 & -4.71 & -5.45 & -6.25 & -7.20 & -8.40 \\
\hline HRH110 & 170.0 & -1.53 & -1.85 & -1.94 & -1.84 & -1.64 & -1.37 & -1.09 & -.86 \\
\hline HRH 110 & 244.0 & -2.69 & -2.75 & -2.90 & -3.09 & -3.23 & -3.28 & -3.19 & -2.88 \\
\hline HRH 110 & 180.0 & .47 & .79 & .94 & .98 & $1 . .02$ & 1.15 & 1.45 & 2.03 \\
\hline HRH111 & 620.0 & .08 & .40 & .68 & .79 & .75 & .46 & .10 & .14 \\
\hline HRH115 & 42.0 & -.43 & -.96 & -1.13 & -1.05 & -.85 & -.64 & -.53 & -.64 \\
\hline \multicolumn{2}{|c|}{ MEANS } & -.34 & -.35 & -.38 & -.38 & -.37 & -.37 & -.36 & -.37 \\
\hline$S^{\circ}$ & VS & 1.68 & 1.71 & 1.84 & 1.92 & 2.02 & 2.18 & 2.58 & 2.69 \\
\hline
\end{tabular}


Table 3: Example of report of VAWR sensor calibration

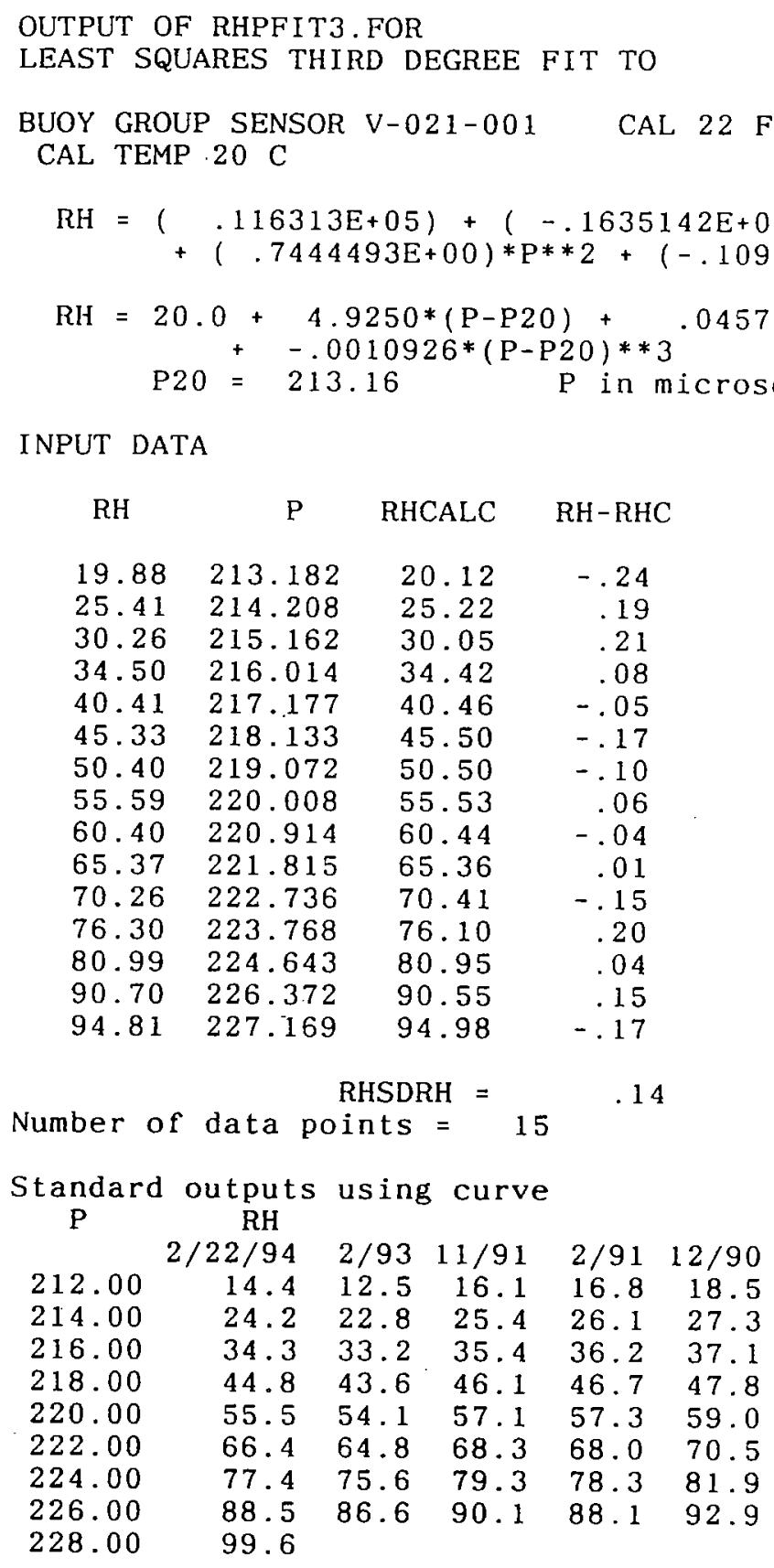


Table 4: Summary of VAWR shifts between calibraitons

\begin{tabular}{|c|c|c|c|c|c|c|c|c|c|c|}
\hline FILE & & & & PUT & DIFS & IV.F & $(8 /$ & $/ 941$ & & \\
\hline SENSOR & DYD & 20 & 30 & 40 & 50 & 60 & 70 & 80 & 90 & \%RH \\
\hline$V-021$ & 1. & .18 & -.99 & -1.52 & -1.56 & -1.26 & -.77 & -.26 & .13 & \\
\hline$V-021$ & 50. & .06 & -.36 & -.63 & -.85 & -1.10 & -1.50 & -2.12 & -3.07 & \\
\hline$V-021$ & 283. & .07 & -.37 & -.54 & -.52 & -.38 & -.20 & -.05 & -.02 & \\
\hline$V-021$ & 463. & -.07 & .30 & .27 & .00 & -.32 & -.54 & -.48 & .02 & \\
\hline$V-021$ & 364 . & -.01 & -.01 & -.15 & -.34 & -.50 & -.53 & -.33 & 17 & \\
\hline$V-022$ & 181 & -.04 & .72 & 1.44 & 2.12 & 2.79 & 3.46 & 4.13 & 4.82 & \\
\hline$V-022$ & 39. & .03 & -.37 & -.46 & -.29 & .09 & .62 & 1.26 & 1.96 & \\
\hline$V-022$ & 149. & .03 & -.30 & -.34 & -.15 & .21 & .65 & 1.10 & 1.51 & \\
\hline$V-022$ & 65 & -.01 & .25 & .52 & .80 & 1.10 & 1.42 & 1.77 & 2.16 & \\
\hline$V-022$ & 725 . & .00 & -.07 & -.11 & -.06 & .14 & .55 & 1.23 & 2.24 & \\
\hline$V-023$ & 59. & -.03 & .17 & .18 & .08 & -.02 & -.03 & .14 & .58 & \\
\hline$V-023$ & 395 . & .00 & -.01 & -.05 & -.04 & .10 & .45 & 1.10 & 2.13 & \\
\hline$V-023$ & 329. & -.02 & .17 & .23 & .28 & .46 & .89 & 1.70 & 3.03 & \\
\hline$V-023$ & 376 . & -.05 & .41 & .61 & .71 & .84 & 1.15 & 1.78 & 2.87 & \\
\hline$V-024$ & 1. & .09 & -.24 & -.14 & .22 & .69 & 1.13 & 1.39 & 1.31 & \\
\hline$V-024$ & 41. & -.01 & .00 & -.13 & -.32 & -.49 & -.56 & -.46 & -.10 & \\
\hline$V-024$ & 395 & .04 & -.16 & -.26 & -.23 & -.09 & 18 & .57 & 1.09 & \\
\hline$V-024$ & 480 & .21 & -.80 & -1.22 & -1.18 & -.79 & -.16 & .60 & 1. 38 & \\
\hline$V-025$ & 652 & .02 & -.13 & -.25 & -.30 & -.22 & .01 & .45 & 1.14 & \\
\hline$V-026$ & 1. & .14 & -.25 & -.15 & .28 & .87 & 1.44 & 1.83 & 1.87 & \\
\hline$V-026$ & 41. & .03 & -.10 & -.22 & -.33 & -.44 & -.56 & -.68 & -.83 & \\
\hline$V-026$ & 224 & -.05 & .29 & .84 & 1.49 & 2.13 & 2.65 & 2.95 & 2.90 & \\
\hline$V-026$ & 464 & .13 & -.46 & -1.04 & -1.53 & -1.88 & -2.04 & -1.95 & -1.54 & \\
\hline$V-026$ & 363 & -.08 & .26 & .56 & .84 & 1.13 & 1.44 & 1.79 & 2.21 & \\
\hline$V-027$ & 1 & .04 & -.06 & .18 & .63 & 1.20 & 1.75 & 2.19 & 2.39 & \\
\hline$V-027$ & 42. & .04 & -.18 & -.26 & -.24 & -.13 & .02 & .19 & .35 & \\
\hline$V-027$ & 223 & .04 & -.18 & -.18 & -.04 & .21 & .49 & .75 & 92 & \\
\hline$V-027$ & 464 & .02 & -.24 & -.62 & -1.00 & -1.29 & -1.35 & -1.09 & -.39 & \\
\hline$V-027$ & 363. & -.02 & .12 & .25 & .41 & .61 & .88 & 1.23 & 1.69 & \\
\hline$V-028$ & 1. & .11 & -.27 & -.07 & 51 & 1.22 & 1.85 & 2.17 & 1.94 & \\
\hline$V-028$ & 265 . & .02 & .07 & .42 & .93 & 1.51 & 2.03 & 2.38 & 2.45 & \\
\hline$V-028$ & 262 . & -.50 & 1.82 & 2.97 & 3.86 & 5.37 & 8.42 & 13.90 & 22.72 & \\
\hline$V-028$ & 21 & .27 & -.95 & -1.34 & -1.16 & $-\because 66$ & -.10 & .27 & .19 & \\
\hline$V-028$ & 180 & -.18 & .79 & 1.46 & 1.89 & 2.15 & 2.31 & 2.42 & 2.58 & \\
\hline$V-028$ & 364 . & -.05 & .31 & .72 & 1.16 & 1.59 & 1.96 & 2.24 & 2.41 & \\
\hline$V-029$ & 1. & .07 & -.15 & .08 & .61 & 1.28 & 1.95 & 2.44 & 2.62 & \\
\hline$V-029$ & 42. & .06 & -.24 & -.38 & -.40 & -.36 & -.27 & -.20 & -.18 & \\
\hline$V-029$ & 394. & .01 & -.04 & -.06 & -.02 & .12 & .37 & .79 & 1.39 & \\
\hline$V-029$ & 91. & .10 & -.34 & -.41 & -.21 & .18 & .69 & 1.23 & 1.72 & \\
\hline$V-029$ & 202 & .05 & -.30 & -.67 & -.99 & -1.19 & -1.19 & -.93 & -.33 & \\
\hline$V-029$ & 363 & -.23 & .93 & 1.57 & 1.87 & 2.02 & 2.22 & 2.64 & 3.47 & \\
\hline$V-030$ & 1. & .00 & .14 & .43 & .82 & 1.25 & 1.67 & 2.01 & 2.23 & \\
\hline$V-030$ & 42. & .00 & -.14 & -.32 & -.52 & -.68 & -.77 & -.76 & -.59 & \\
\hline$V-031$ & 223 & .00 & -.12 & -.21 & -.28 & -.30 & -.30 & -.26 & -.19 & \\
\hline$V-031$ & 151 & .01 & .39 & .45 & .31 & .07 & -.13 & -.20 & .01 & \\
\hline$V-031$ & 313 & .00 & .06 & -.03 & -.19 & -.35 & -.46 & -.43 & -.19 & \\
\hline$V-031$ & 412. & .01 & .32 & .42 & .41 & .41 & .51 & .83 & 1.48 & \\
\hline$v-032$ & 223 . & .04 & -.31 & -.51 & -.59 & -.58 & -.51 & -.42 & -.33 & \\
\hline$V-032$ & 151 & -.19 & 1.33 & 1.96 & 2.23 & 2.71 & 3.96 & 6.54 & 11.00 & \\
\hline$V-032$ & 105 & .00 & -.01 & -.04 & -.01 & .11 & .38 & .85 & 1.57 & \\
\hline$V-032$ & 620. & -.03 & .18 & .22 & 14 & $-.0 \mathrm{I}$ & -.15 & -.24 & -.21 & \\
\hline$V-033$ & 102. & .00 & -.53 & -.63 & -.44 & -.10 & .26 & .48 & .43 & \\
\hline$V-033$ & 827 . & .00 & -.07 & -.03 & .11 & .34 & .64 & 1.02 & 1.45 & \\
\hline$V-034$ & 312 . & -.01 & .66 & 1.09 & 1.34 & 1.50 & 1.62 & 1.78 & 2.04 & \\
\hline$V-034$ & 364 . & -.01 & .57 & 1.13 & 1.67 & 2.23 & 2.82 & 3.46 & 4.16 & \\
\hline \multicolumn{2}{|c|}{ MEANS } & .01 & .03 & .09 & .22 & .43 & .74 & 1.18 & 1.76 & \\
\hline STD DI & & .11 & .49 & .79 & .99 & 1.23 & 1.62 & 2.29 & 3.45 & \\
\hline
\end{tabular}


Table 5: Summary of IMET shifts due to $10^{\circ} \mathrm{C}$ temperature difference

\begin{tabular}{lrrrrrrrr} 
MOD & 20 & 30 & \multicolumn{1}{c}{40} & \multicolumn{1}{c}{50} & \multicolumn{1}{c}{60} & \multicolumn{1}{c}{70} & 80 & $90 \% \mathrm{RH}$ \\
HRH001 & -2.40 & -2.04 & -1.34 & -.48 & .38 & 1.07 & 1.45 & 1.36 \\
HRH002 & -1.81 & -1.22 & -.41 & .45 & 1.20 & 1.70 & 1.77 & 1.25 \\
HRH003 & -.77 & -.23 & .44 & 1.13 & 1.71 & 2.03 & 1.99 & 1.44 \\
HRH004 & -2.70 & -2.22 & -1.45 & -.54 & .35 & 1.05 & 1.39 & 1.22 \\
HRH005 & -1.31 & -.87 & .08 & 1.29 & 2.52 & 3.54 & 4.11 & 3.98 \\
HRH006 & -1.67 & -1.21 & -.56 & .18 & .88 & 1.40 & 1.61 & 1.39 \\
MEANS & -1.78 & -1.30 & -.54 & .34 & 1.17 & 1.80 & 2.05 & 1.77 \\
SD & .64 & .68 & .69 & .71 & .76 & .85 & .94 & .99
\end{tabular}

Table 6: Summary of VAWR shifts due to $10^{\circ} \mathrm{C}$ temperature difference

$\begin{array}{crrrrrrrr}\text { SEN } & 20 & 30 & 40 & 50 & 60 & 70 & 80 & 90 \% \mathrm{RH} \\ \mathrm{V}-021 & 1.2 & .2 & -.4 & -.4 & -.2 & .4 & .9 & 1.2 \\ \mathrm{~V}-024 & -2.2 & -2.8 & -2.8 & -2.5 & -2.1 & -1.6 & -1.3 & 1.3 \\ \mathrm{~V}-026 & -1.9 & -2.2 & -2.0 & -1.5 & -.9 & -.4 & .0 & .1 \\ \mathrm{~V}-027 & -1.9 & -2.4 & -2.5 & -2.1 & -1.6 & -1.1 & -.6 & -.1 \\ \mathrm{~V}-028 & -.8 & -1.7 & -.9 & -1.5 & -.8 & -.2 & .4 & .4 \\ \text { V-029 } & -1.8 & -2.1 & -2.0 & -1.6 & -.8 & -.2 & .3 & .5 \\ \mathrm{~V}-030 & -3.0 & -3.0 & -2.8 & -2.5 & -2.1 & -1.5 & -1.1 & -.7 \\ \text { MEANS } & -1.7 & -2.3 & -2.2 & -2.0 & -1.4 & -.8 & -.2 & .5 \\ \text { SD } & 1.4 & 1.1 & 1.0 & .8 & .8 & .8 & .8 & .7\end{array}$




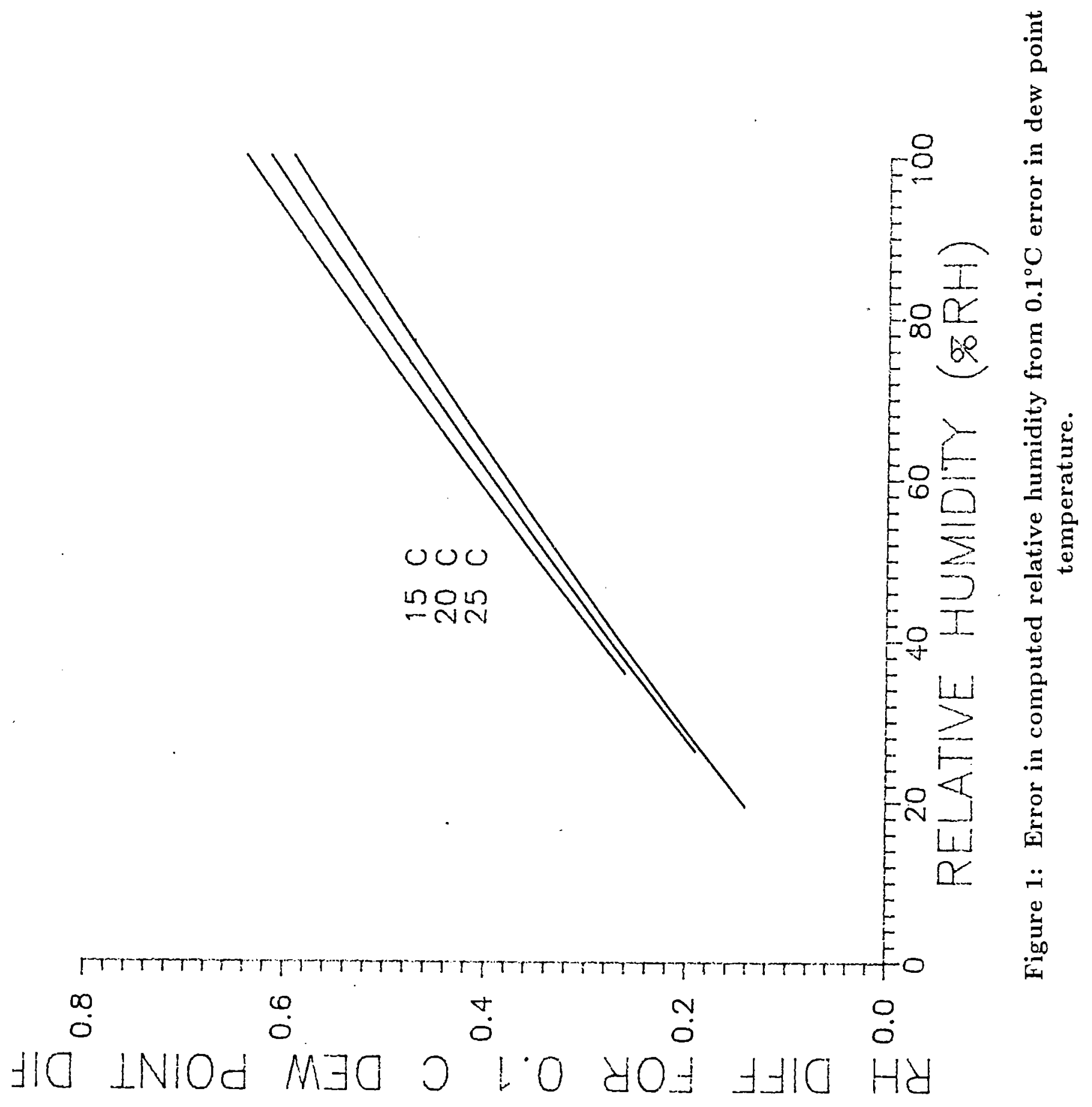




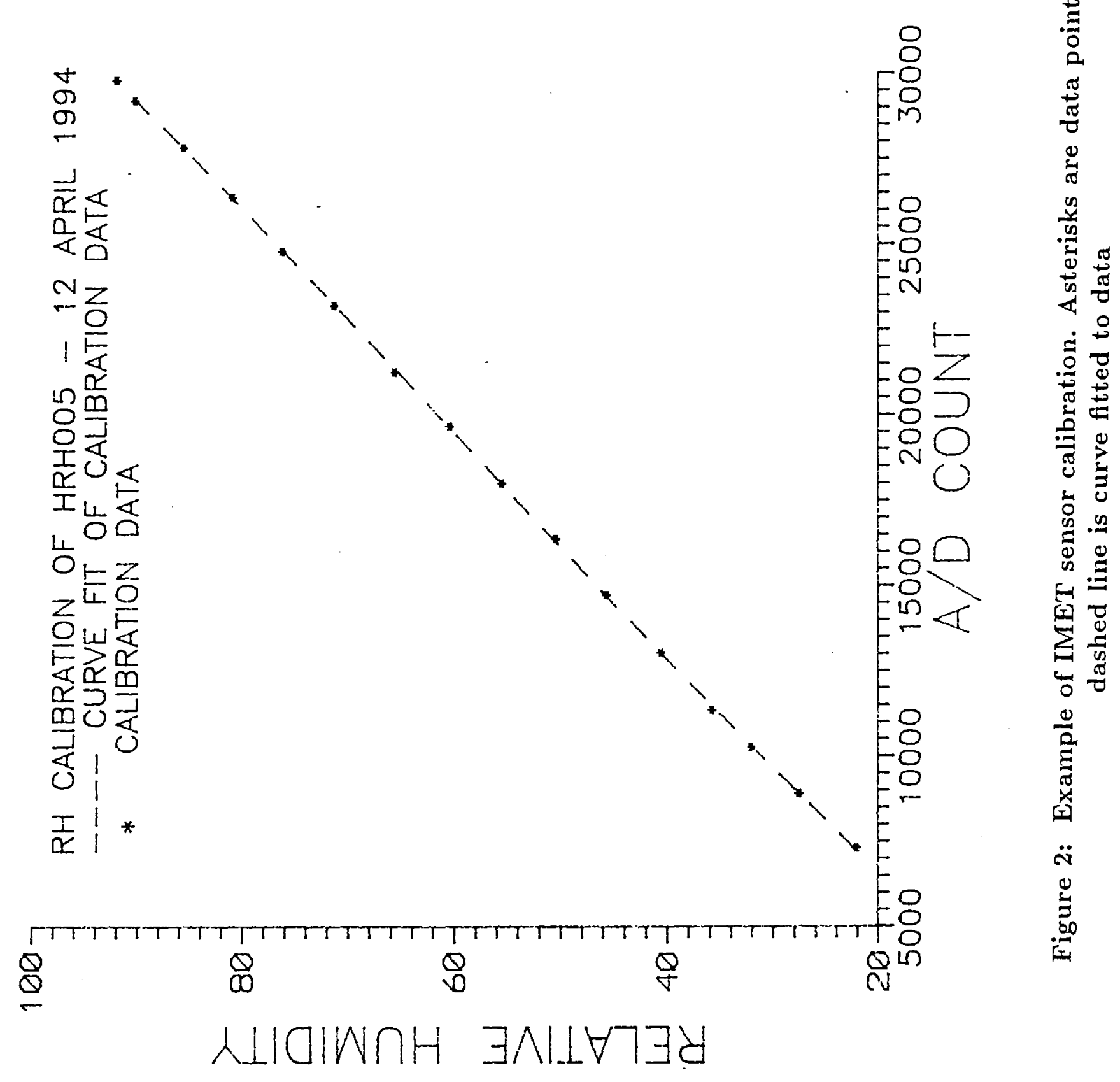




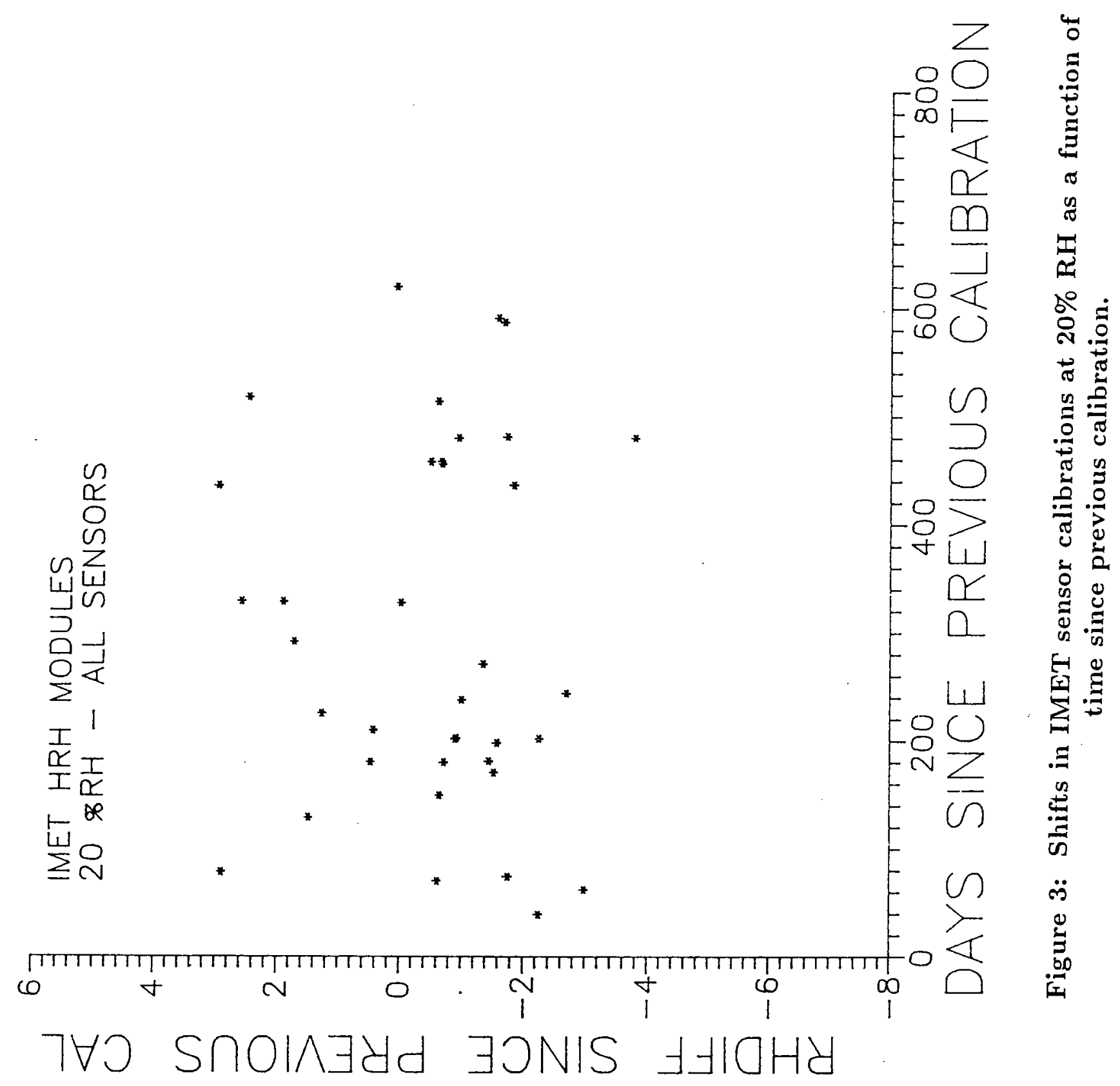




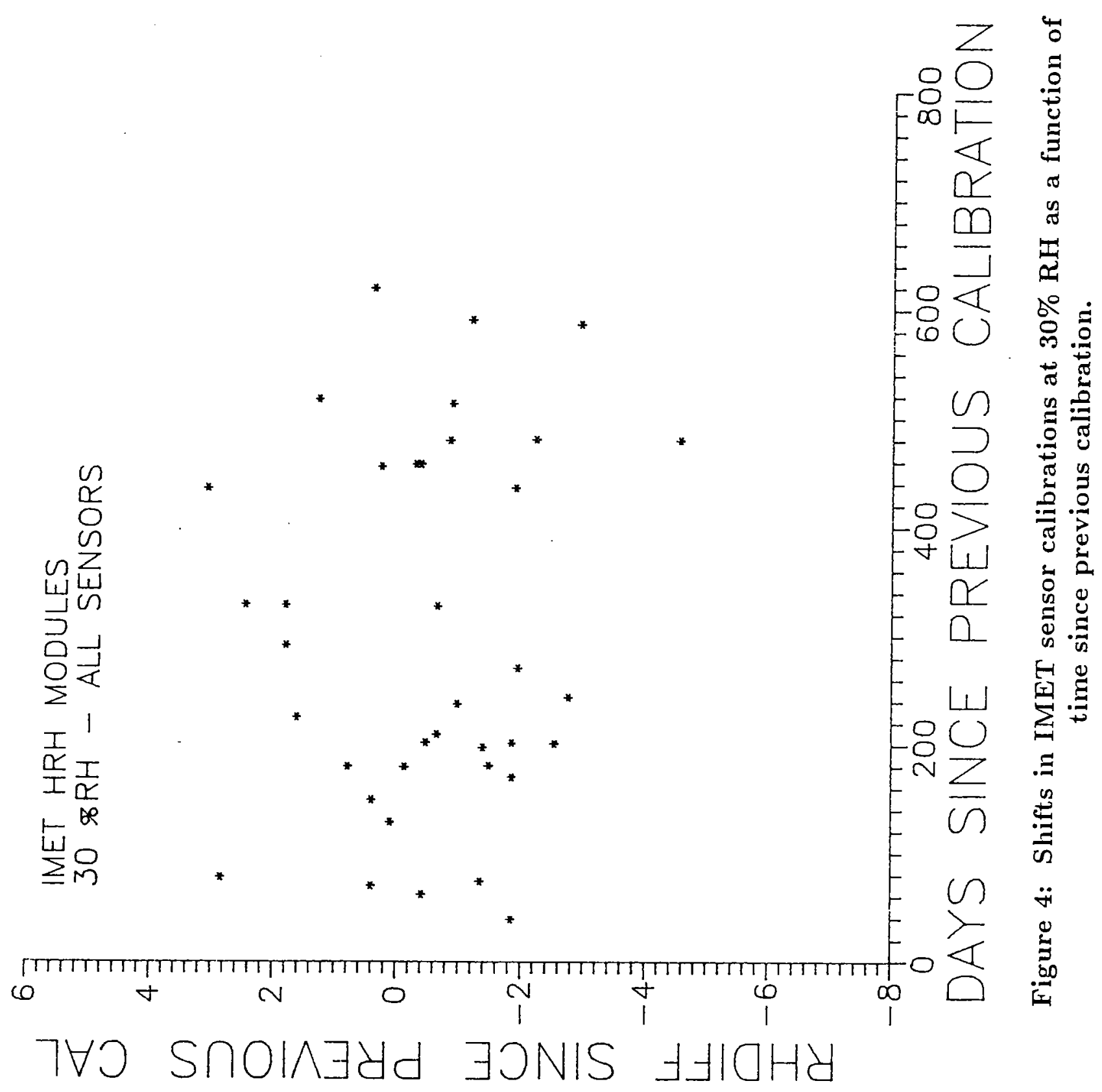




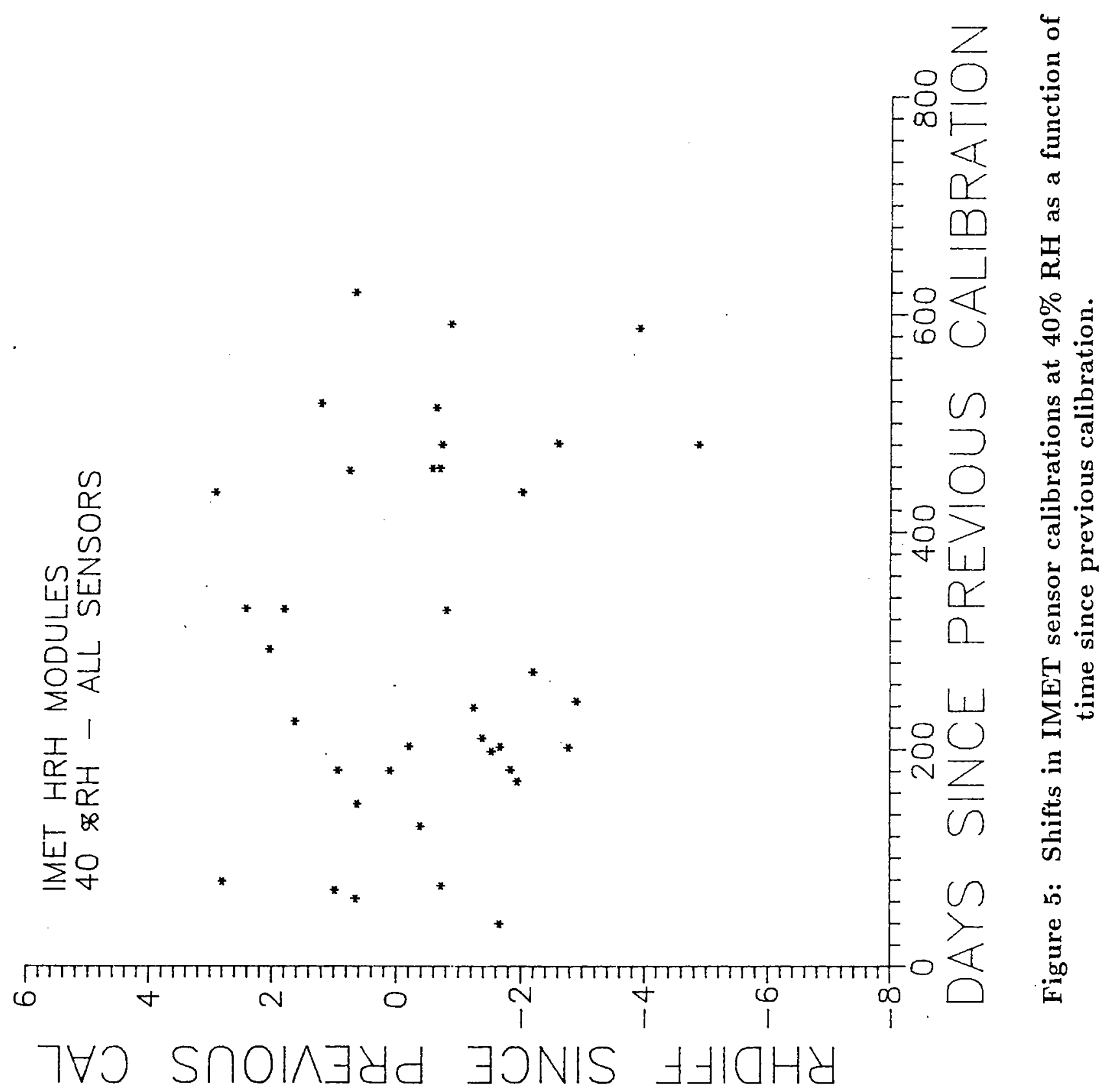




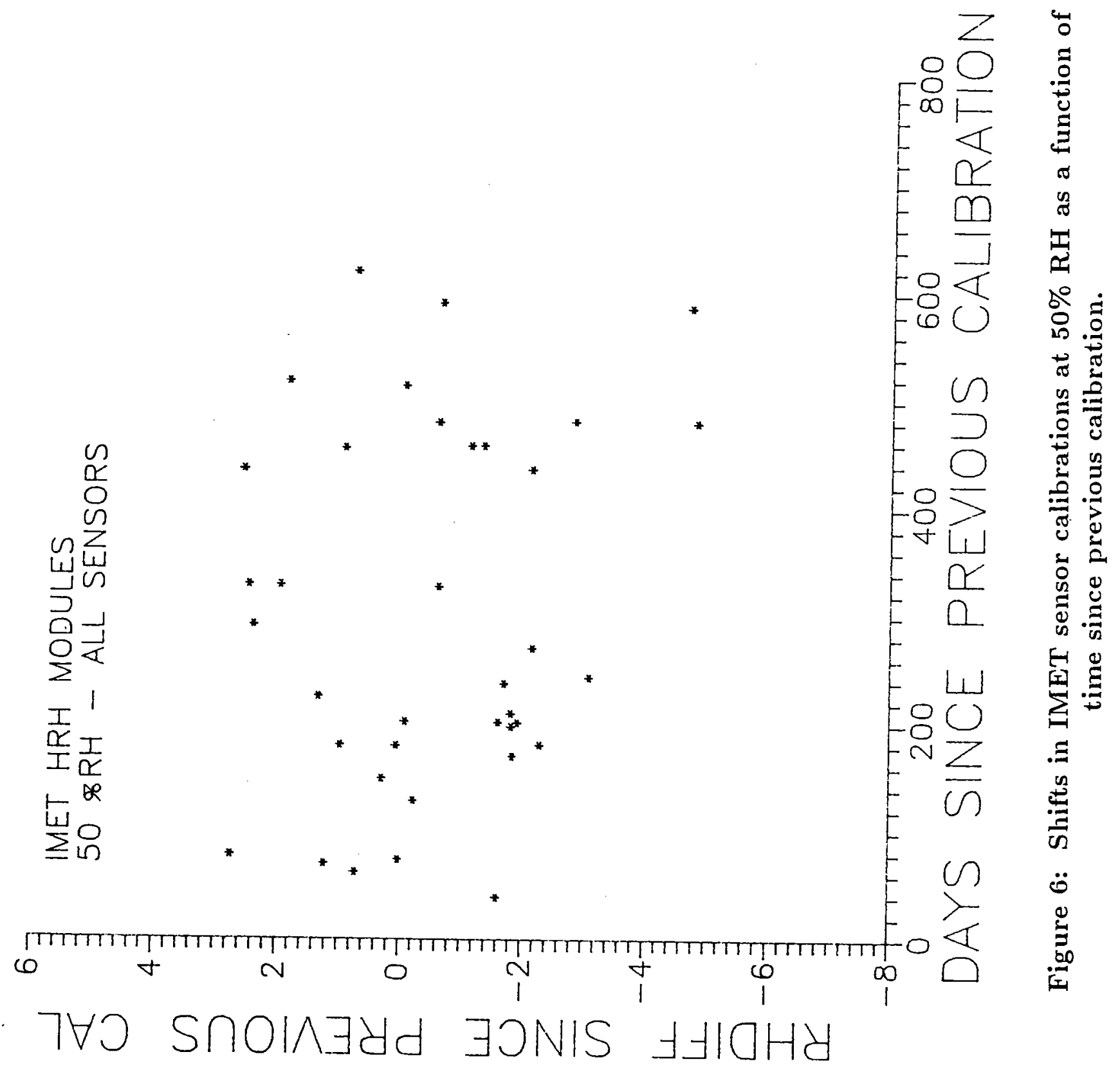




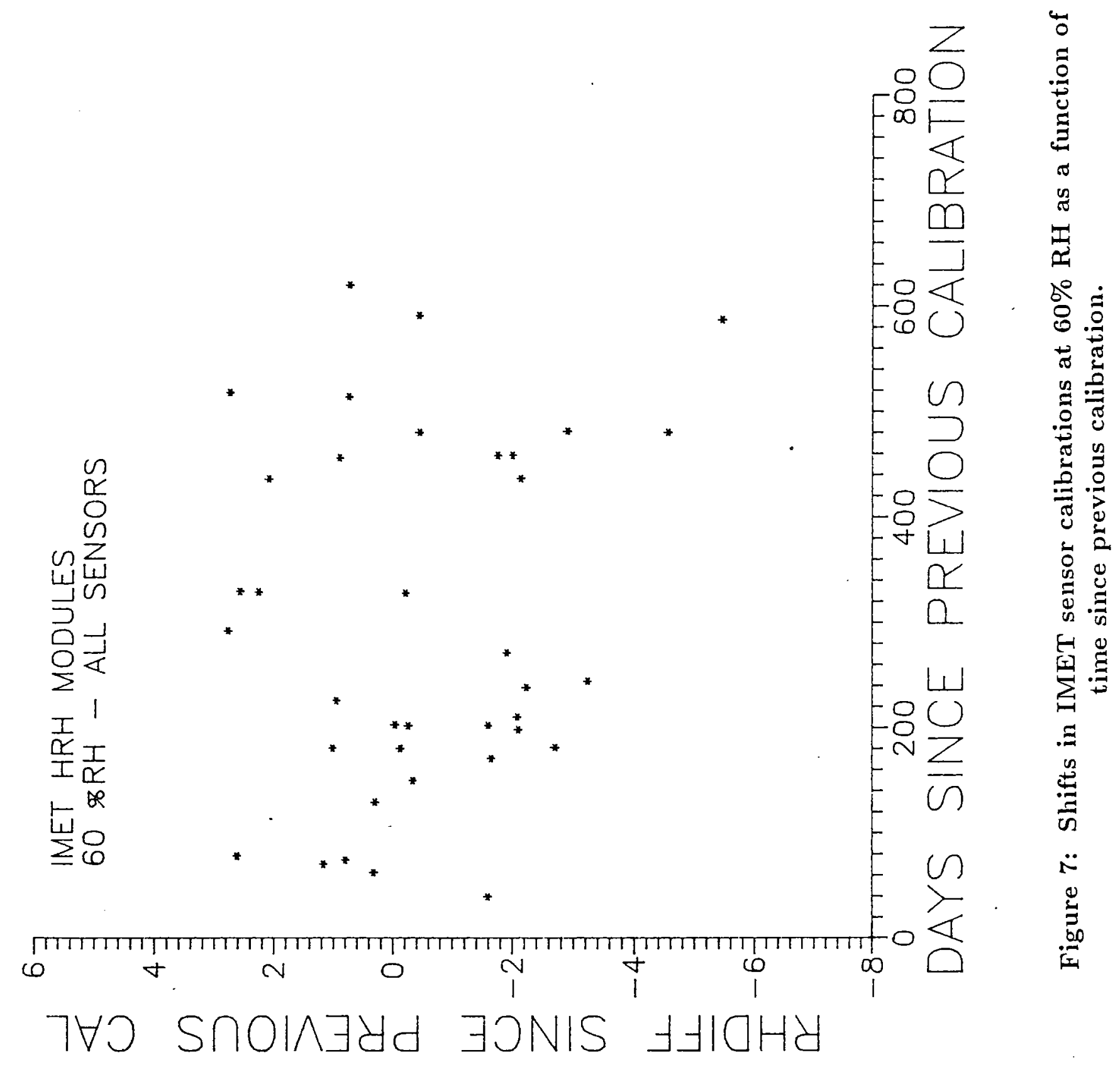




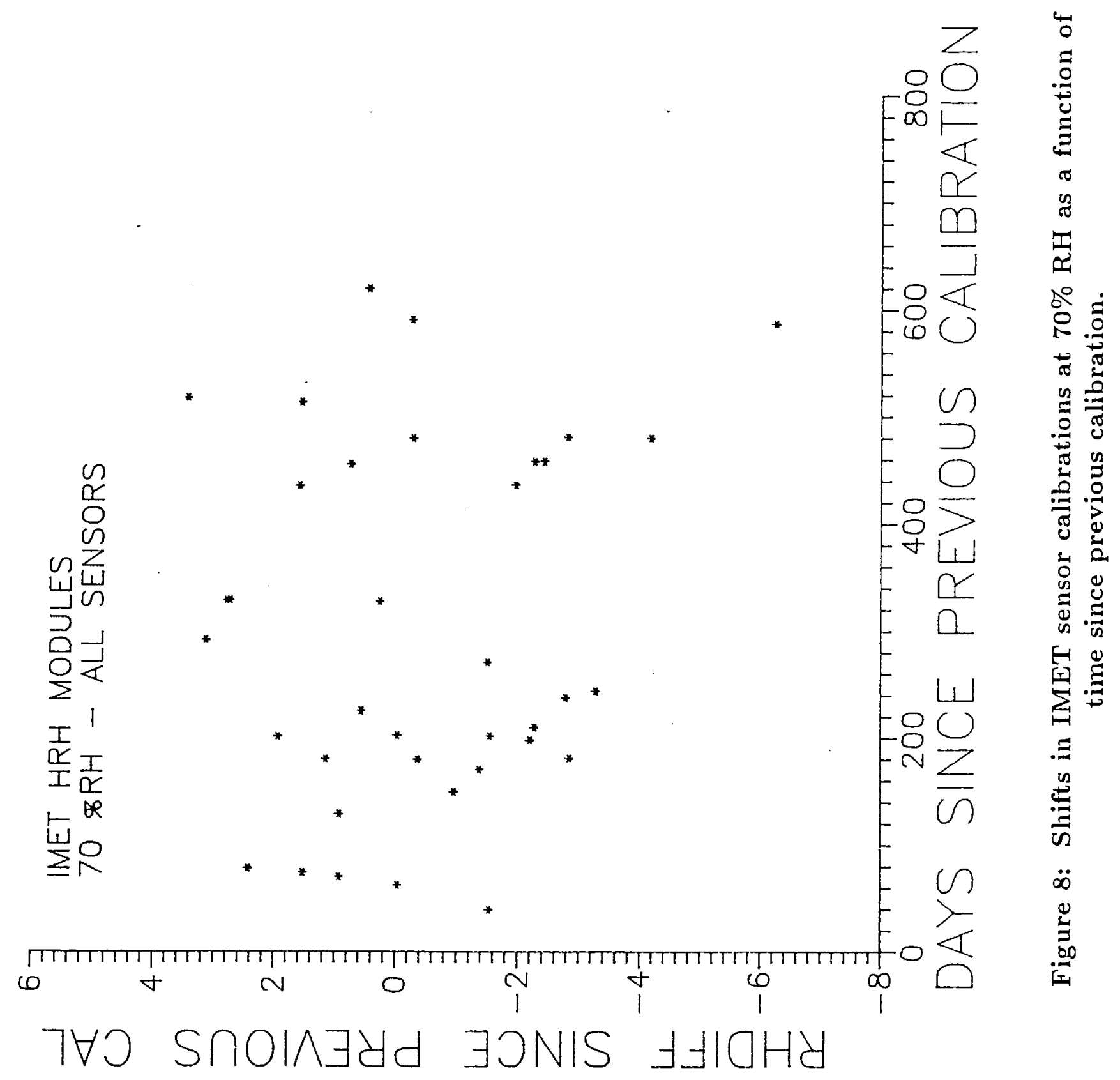




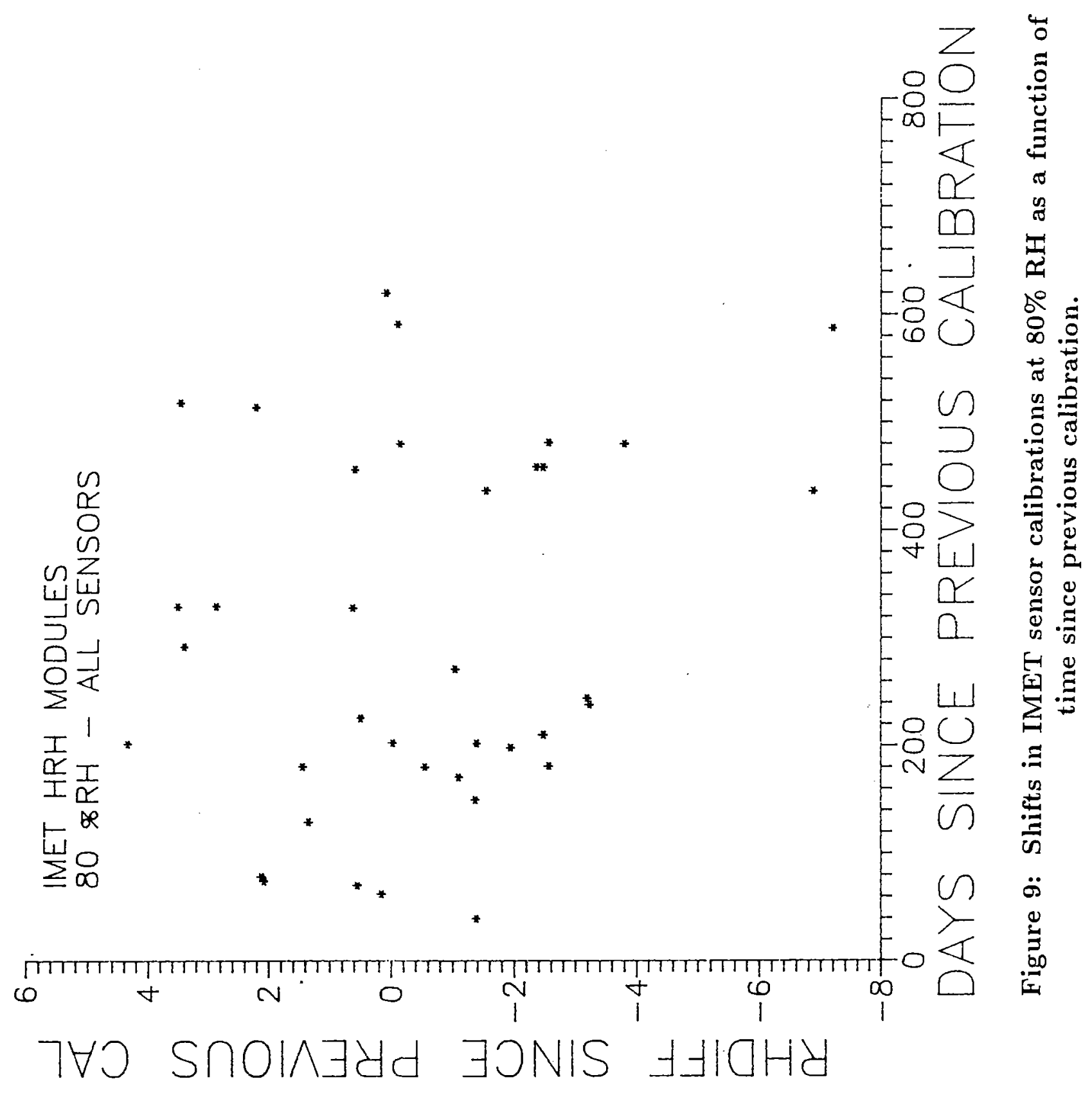




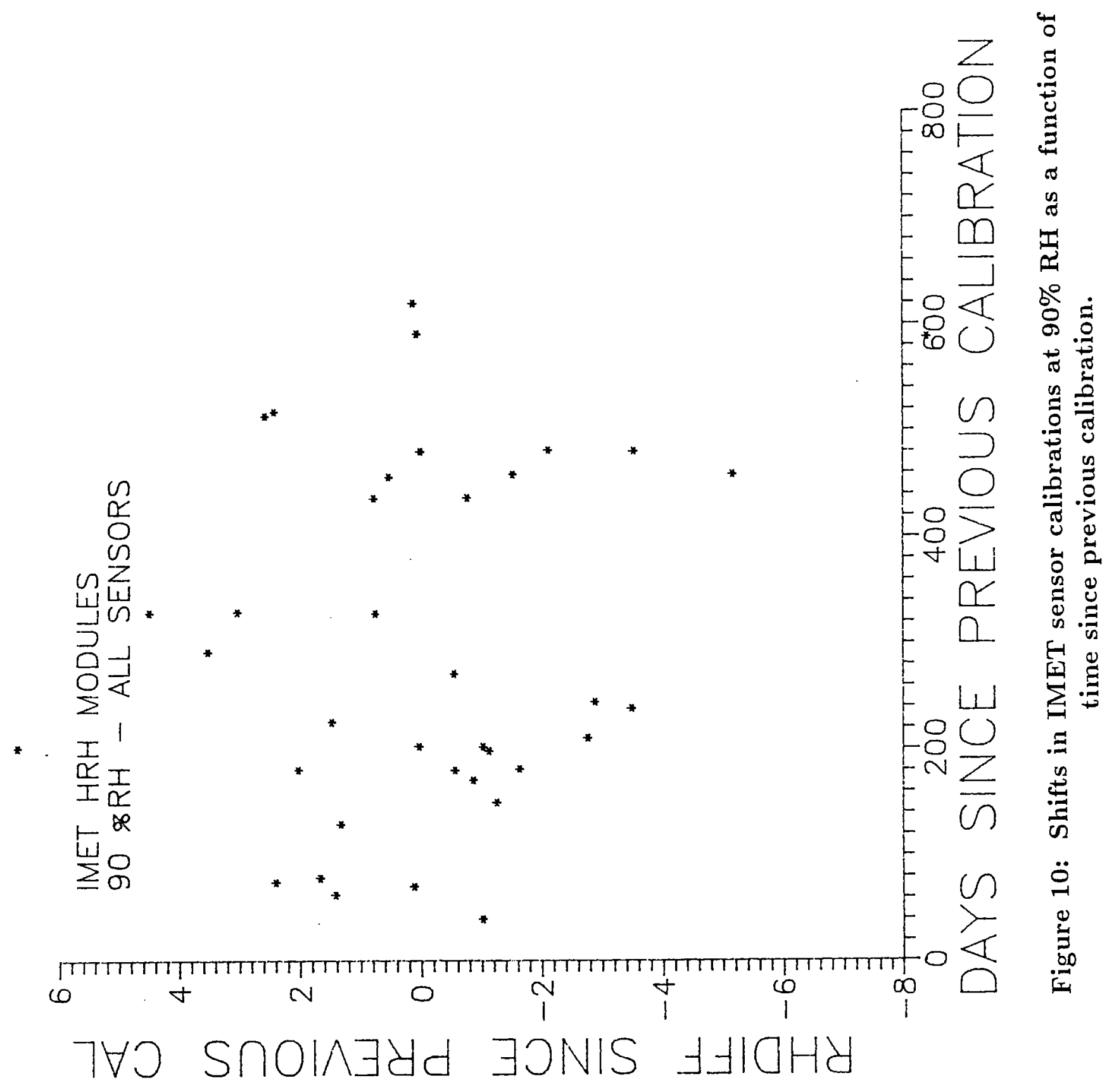




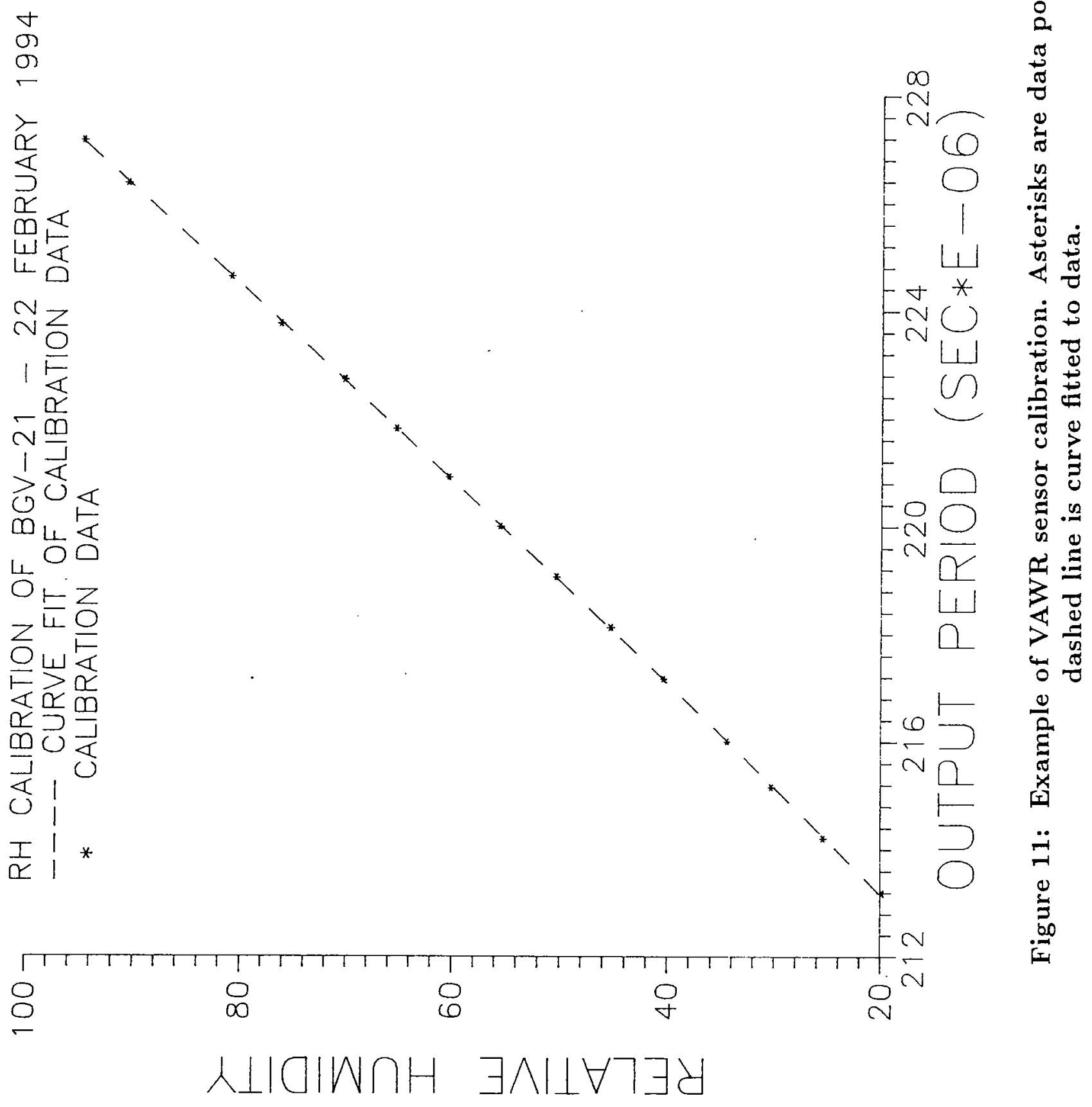




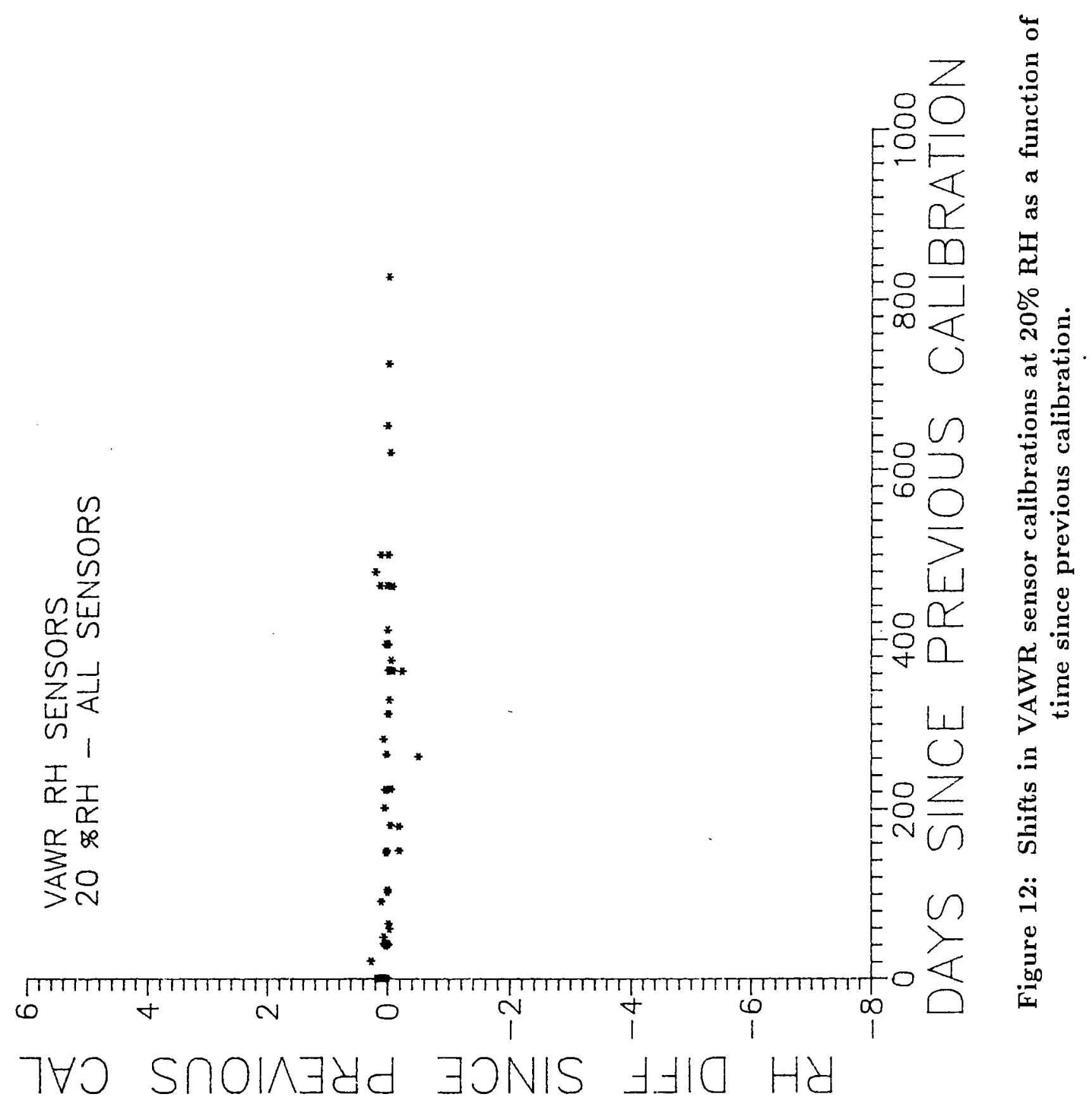




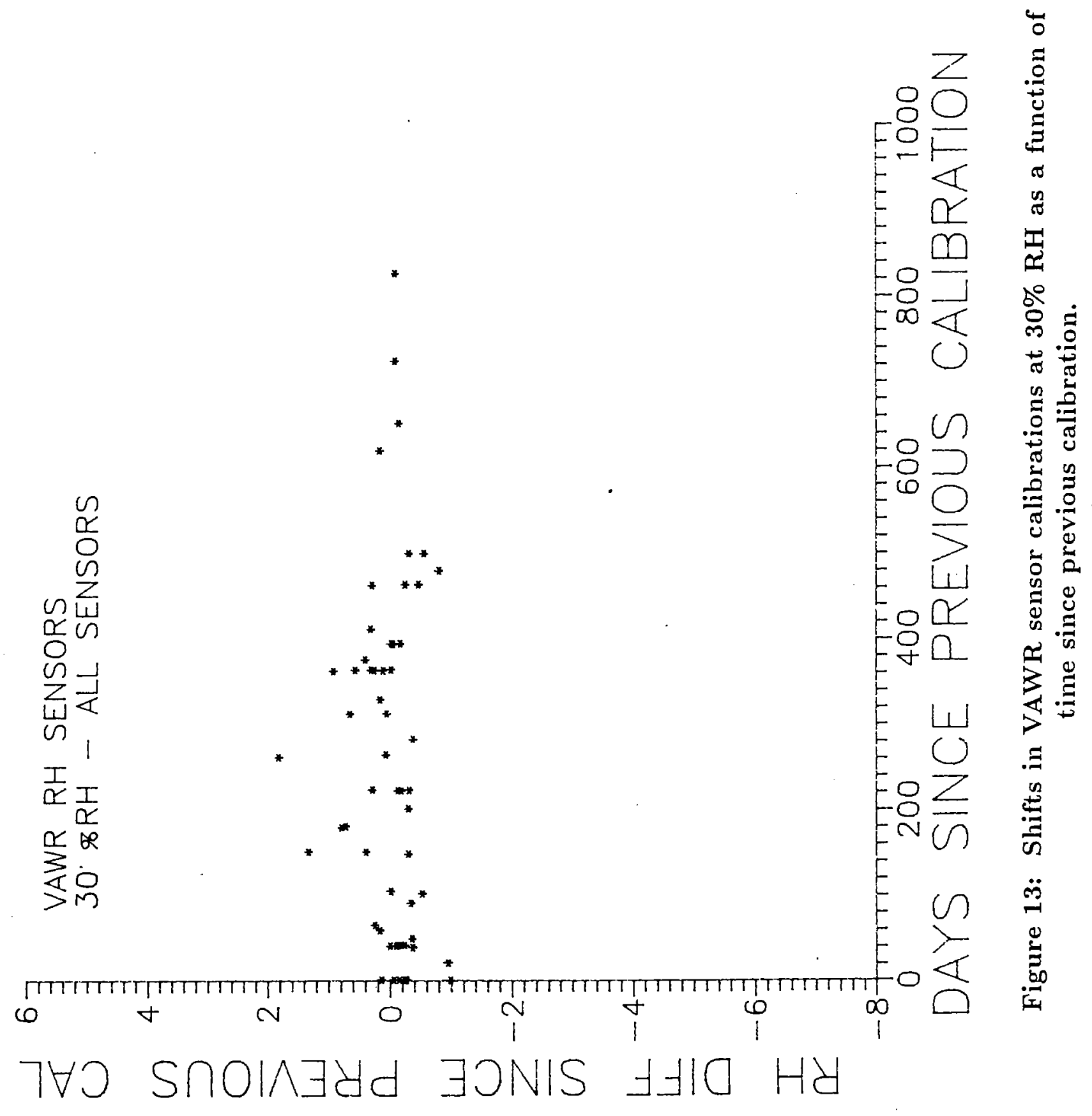




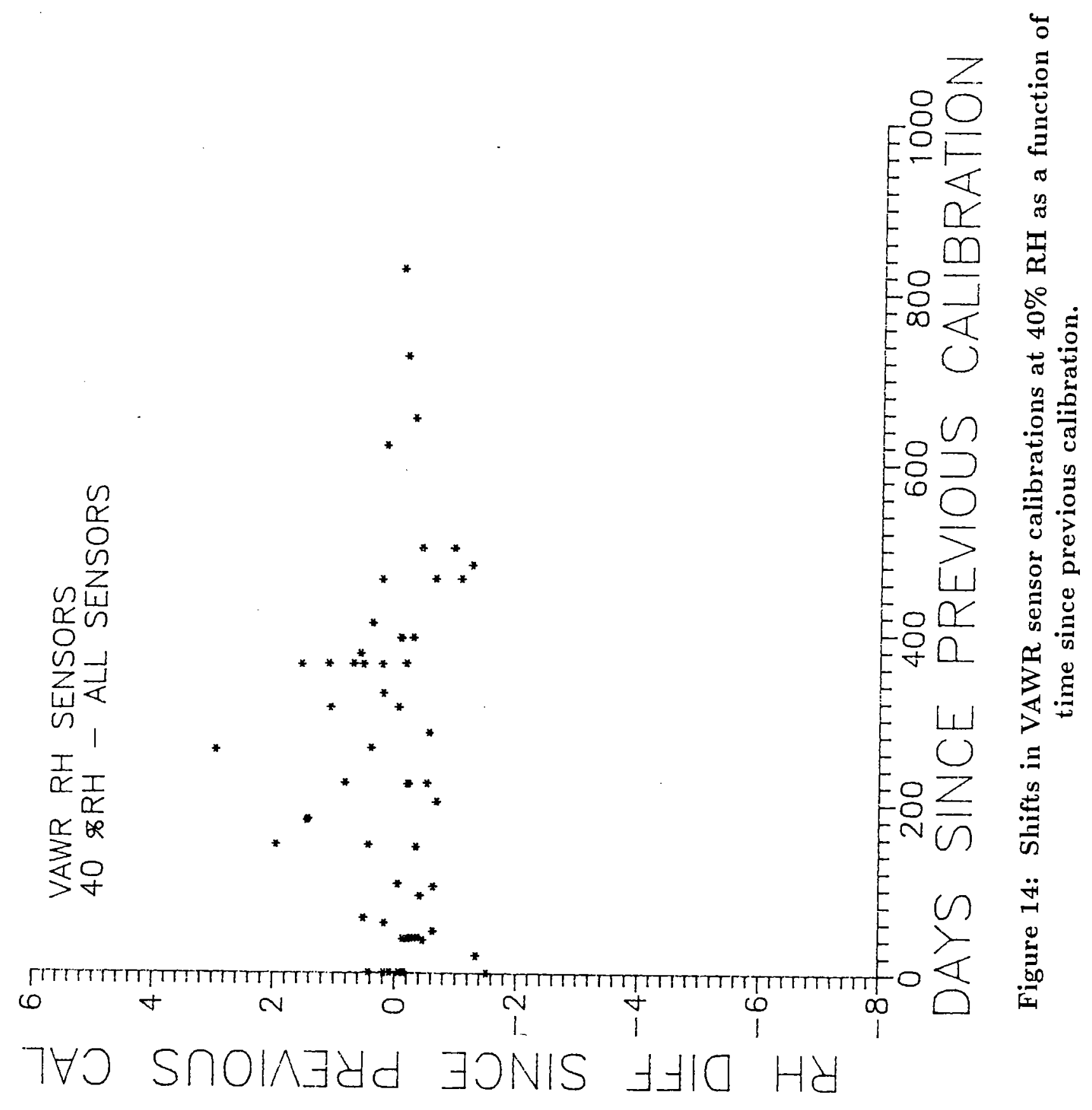




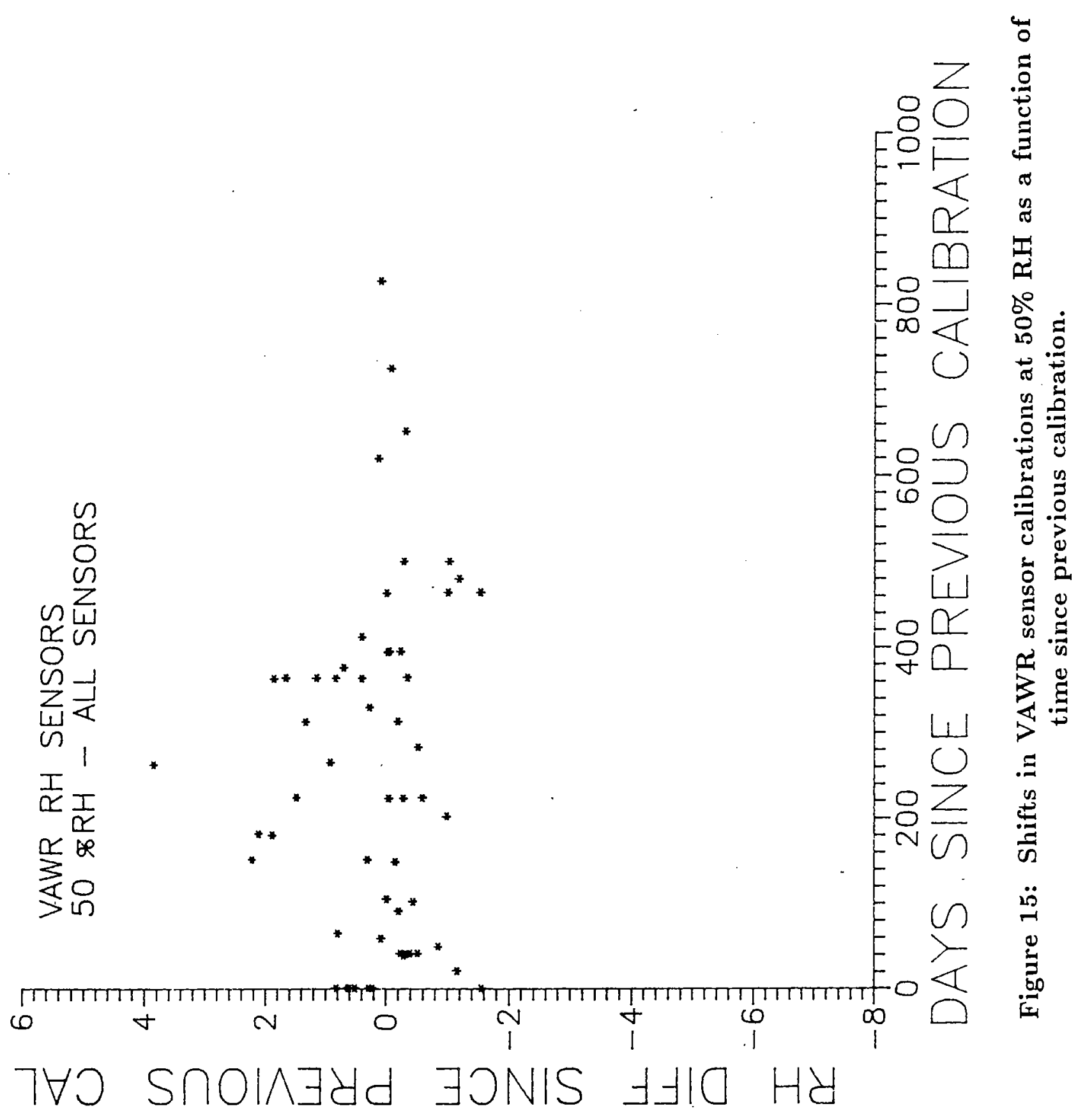




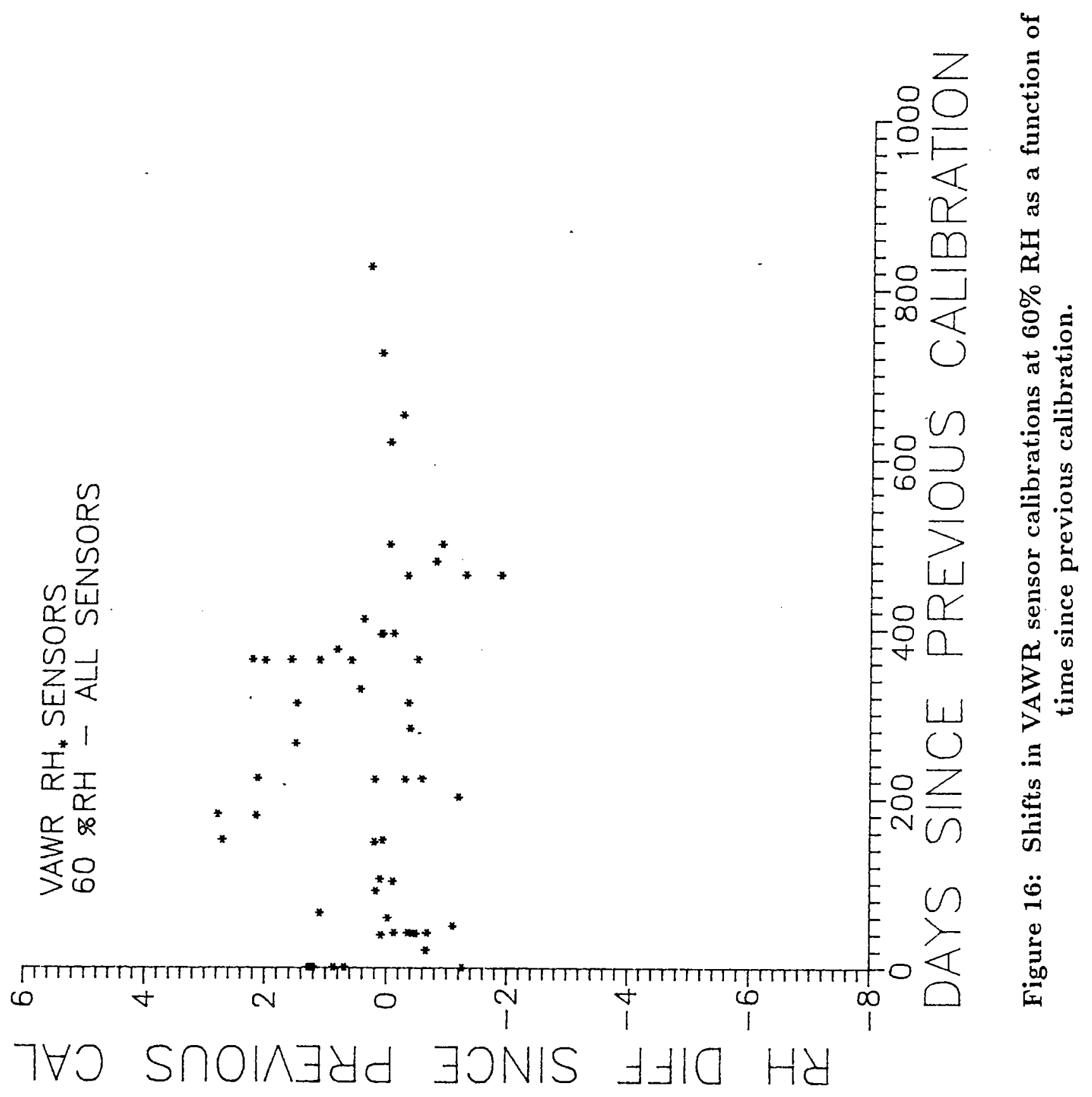




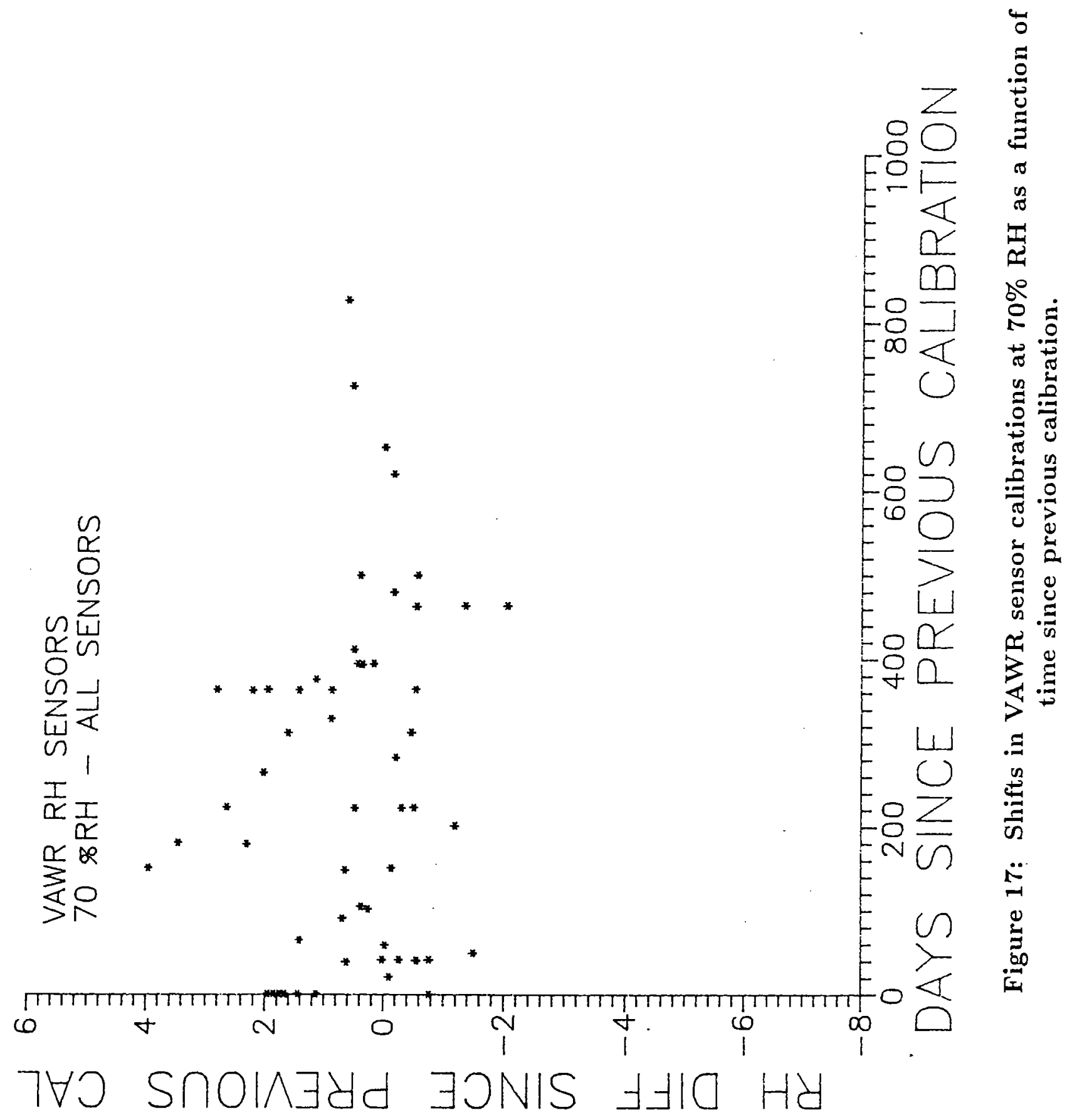




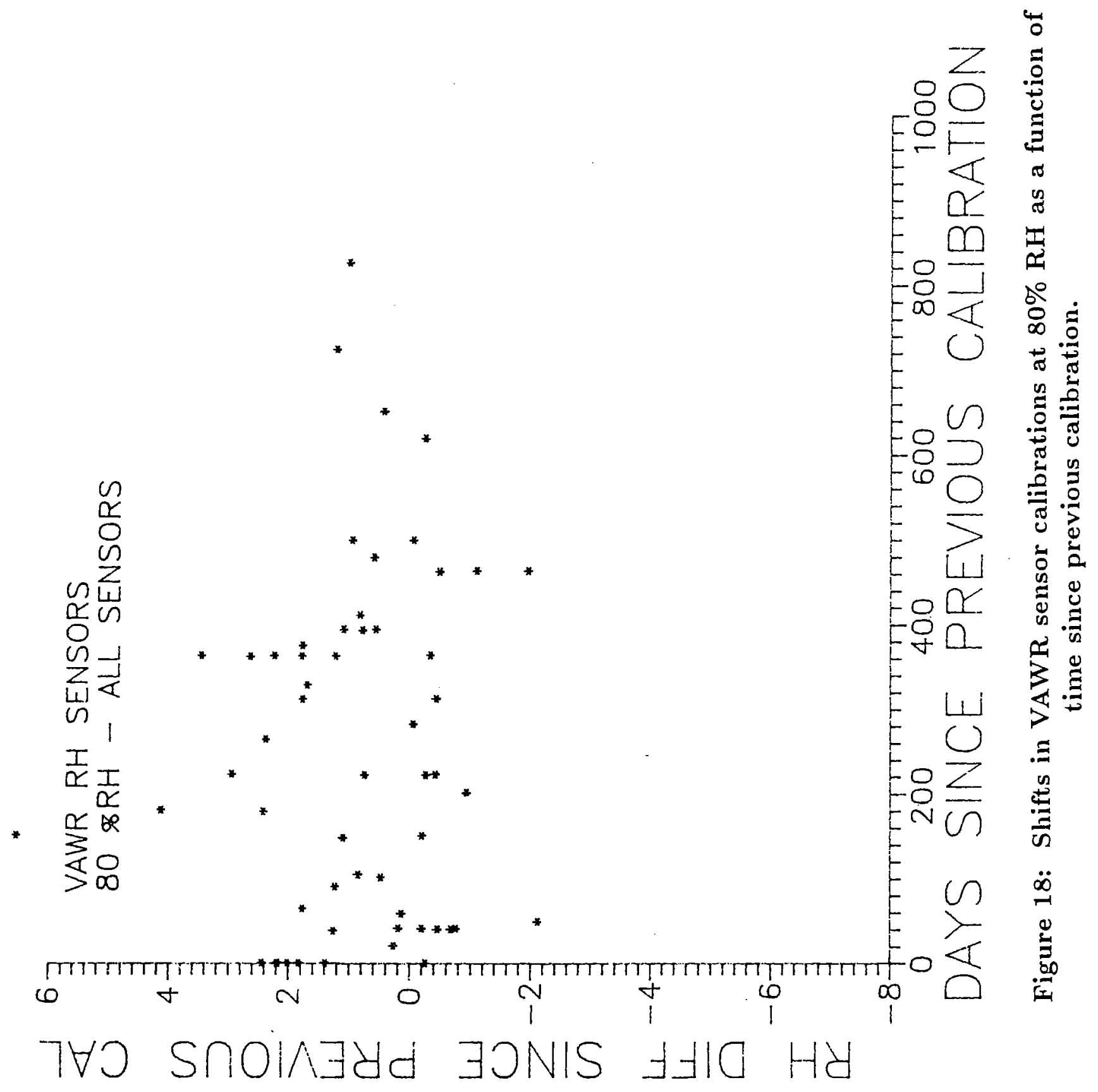




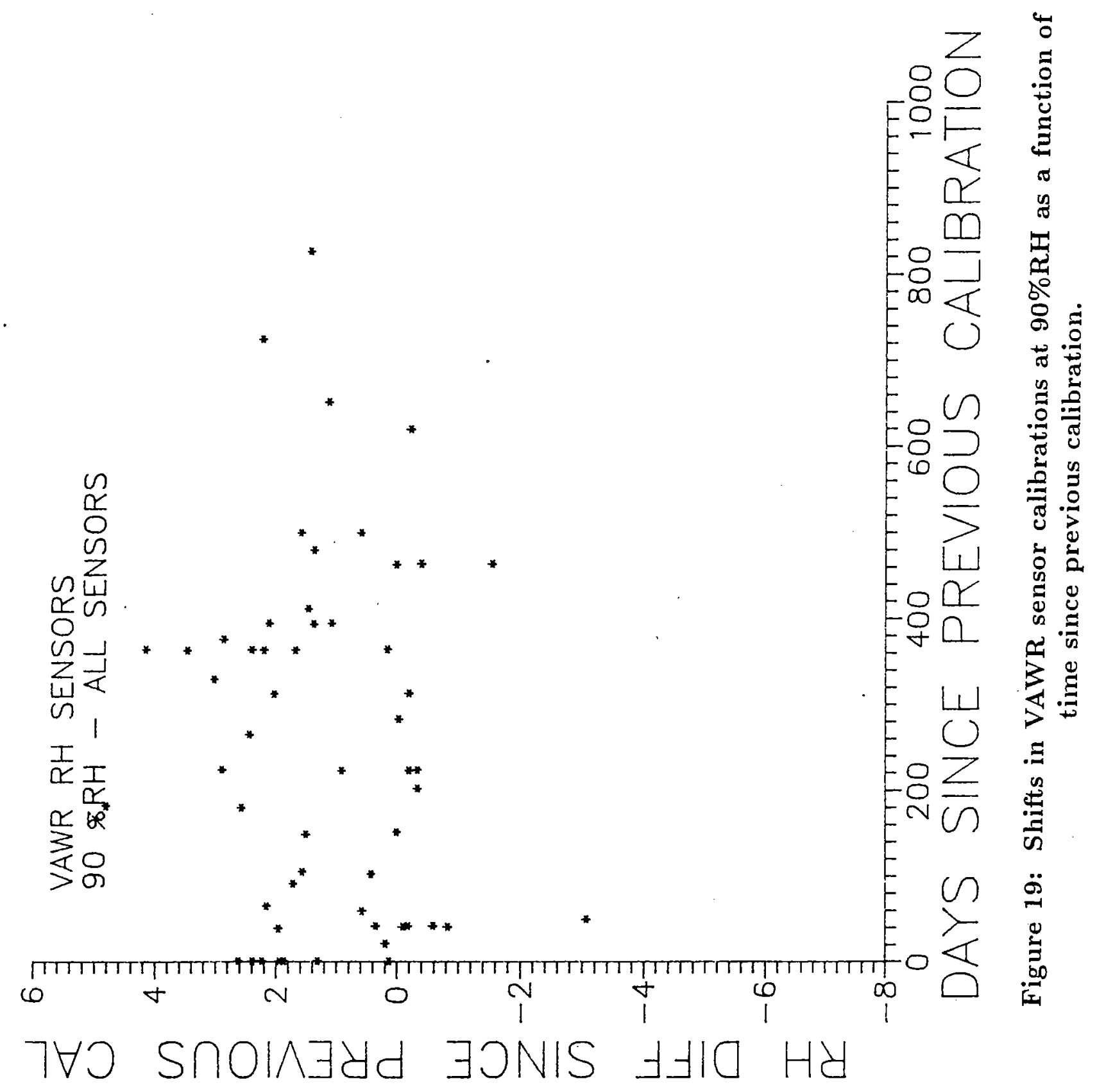




\section{DOCUMENT LIBRARY}

Distribution List for Technical Report Exchange - May 5, 1994

University of California, San Diego

SIO Library 0175C (TRC)

9500 Gilman Drive

La Jolla, CA 92093-0175

Hancock Library of Biology \& Oceanography

Alan Hancock Laboratory

University of Southern California

University Park

Los Angeles, CA 90089-0371

Gifts \& Exchanges

Library

Bedford Institute of Oceanography

P.O. Box 1006

Dartmouth, NS, B2Y 4A2, CANADA

Commander

International Ice Patrol

1082 Shennecossett Road

Groton, CT 06340-6095

NOAA/EDIS Miami Library Center

4301 Rickenbacker Causeway

Miami, FL 33149

Library

Skidaway Institute of Oceanography

10 Ocean Science Circle

Savannah, GA 31411

Institute of Geophysics

University of Hawaii

Library Room 252

2525 Correa Road

Honolulu, HI 96822

Marine Resources Information Center

Building E38-320

MIT

Cambridge, MA 02139

Library

Lamont-Doherty Geological Observatory

Columbia University

Palisades, NY 10964

Library

Serials Department

Oregon State University

Corvallis, OR 97331

Pell Marine Science Library

University of Rhode Island

Narragansett Bay Campus

Narragansett, RI 02882
Working Collection

Texas A\&M University

Dept. of Oceanography

College Station, TX 77843

Fisheries-Oceanography Library 151 Oceanography Teaching Bldg.

University of Washington

Seattle, WA 98195

Library

R.S.M.A.S.

University of Miami

4600 Rickenbacker Causeway

Miami, FL 33149

Maury Oceanographic Library

Naval Oceanographic Office

Building 1003 South

1002 Balch Blvd.

Stennis Space Center, MS 39522-5001

Library

Institute of Ocean Sciences

P.O. Box 6000

Sidney, B.C. V8L 4B2

CANADA

Library

Institute of Oceanographic Sciences

Deacon Laboratory

Wormley, Godalming

Surrey GU8 5UB

UNITED KINGDOM

The Librarian

CSIRO Marine Laboratories

G.P.O. Box 1538

Hobart, Tasmania

AUSTRALIA 7001

Library

Proudman Oceanographic Laboratory

Bidston Observatory

Birkenhead

Merseyside L43 7 RA

UNITED KINGDOM

IFREMER

Centre de Brest

Service Documentation - Publications

BP 7029280 PLOUZANE

FRANCE 


\begin{tabular}{|c|c|c|c|}
\hline $\begin{array}{l}\text { REPORT DOCUMENTATION } \\
\text { PAGE }\end{array}$ & 1. REPORT NO. WHOI-94-28 & \begin{tabular}{|lll} 
UOP & Report $94-3$ \\
\end{tabular} & 3. Recipient's Accession No. \\
\hline \multirow{2}{*}{\multicolumn{3}{|c|}{$\begin{array}{l}\text { 4. Title and Subtitle } \\
\text { Calibration History of Some Rotronic MP-100 and Vaisala Humicap Relative } \\
\text { Humidity Sensors }\end{array}$}} & $\begin{array}{l}\text { 5. Report Date } \\
\text { September } 1994\end{array}$ \\
\hline & & & 6 \\
\hline \multicolumn{3}{|l|}{ 7. Author(s) Richard E. Payne } & $\begin{array}{l}\text { 8. Performing Organization Rept. No. } \\
\text { WHOI-94-28 }\end{array}$ \\
\hline \multirow{2}{*}{\multicolumn{3}{|c|}{$\begin{array}{l}\text { 9. Performing Organization Name and Address } \\
\text { Woods Hole Oceanographic Institution } \\
\text { Woods Hole, Massachusetts } 02543 \text { U.S.A. }\end{array}$}} & 10. Project/Task/Work Unit No. \\
\hline & & & $\begin{array}{l}\text { 11. Contract(C) or Grant(G) No. } \\
\text { (C) OCE-91-15000 } \\
\text { (G) }\end{array}$ \\
\hline \multirow{2}{*}{\multicolumn{2}{|c|}{$\begin{array}{l}\text { 12. Sponsoring Organization Name and Address } \\
\text { National Science Foundation }\end{array}$}} & \multirow[b]{2}{*}{ - } & $\begin{array}{l}\text { 13. Type of Report \& Period Covered } \\
\text { Technical Report }\end{array}$ \\
\hline & & & 14. \\
\hline
\end{tabular}

\section{Supplementary Notes}

This report should be cited as: Woods Hole Oceanog. Inst. Tech. Rept., WHOI-94-28.

16. Abstract (Limit: 200 words)

An analysis has been made of the calibrations done during 1990 through 1994 on Rotronic MP-100 relative humidity sensors (used in the Improved METeorological (IMET) system and sensors built at the Woods Hole Oceanographic Institution (WHOI) with the Vaisala Humicap sensing element (used in the Vector Averaging Wind Recorder (VAWR)). The shift from one calibration to the next is, typically, 2-3\% RH which represents the major uncertainty in relative humidity with either of these sensors. The direction of each shift appears to be random; thus, there does not appear to be any long-term drifts.

17. Document Analysis a. Descriptors

Rotronic

Vaisala

RH sensor calibration stability

b. Identifiers/Open-Ended Terms

c. COSATI Field/Group

18. Availability Statement

Approved for public release; distribution unlimited.

19. Security Class (This Report)

UNCLASSIFIED

20. Security Class (This Page)
21. No. of Pages 37

22. Price 